\title{
Production and Marketing of Red Meat, Wool, Skins and Hides in Afghanistan
}

\section{A Case Study from Kabul, Kandahar and Kunduz Provinces}

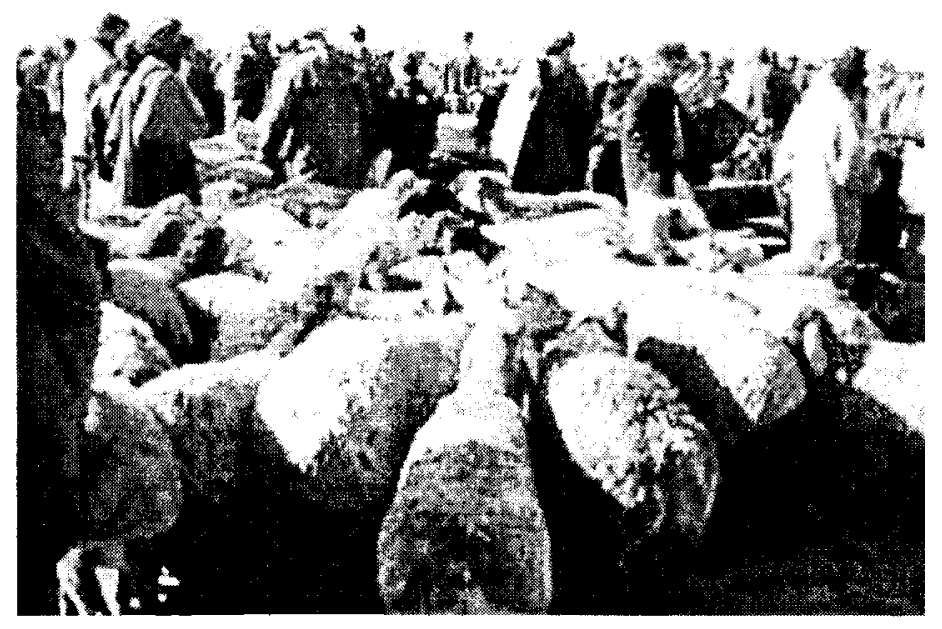

Euan F. Thomson, Philippe Chabot, and lain A. Wright 
The Macaulay Institute, based in Aberdeen, UK brings together many disciplines to develop a better understanding of the environment and society's interactions and impacts on it; the quality and relevance of our work have established the Institute as a premier centre for land use research in Europe. The Institute's goal is 'research today for land use tomorrow'.

The Institute has 300 staff and students including soil, plant and animal scientists, geographers, socio-economists and IT specialists who work together in interdisciplinary teams to meet the needs of land managers and policy makers in the UK, Europe and worldwide.

Our research is concerned with the physical, environmental and social consequences of land use and focuses on:

- the quality of life, the public good and wealth creation

- the impact of land use on environmental quality, and

- evaluating the trade-offs between the environmental, economic and social objectives of land use.

This project was conducted by Macaulay Research Consultancy Services Ltd, the consultancy arm of the Macaulay Institute

Mercy Corps is an international nonprofit organisation with headquarters offices in Edinburgh, (Scotland), Portland (Oregon), Seattle (Washington), Cambridge (Massachusetts), and Washington, DC.

Since 1979, Mercy Corps has provided over $£ 650$ million in assistance to people in 81 nations. Mercy Corps is known nationally and internationally for its quick-response, highimpact programmes. Over 92 percent of the agency's resources are allocated directly to programmes that help those in need.

Since 2002 we have increased our efforts to ease the suffering of the Afghan people as millions of refugees return to the war-ravaged homes and villages. We run many different projects in Afghanistan, as the need for our help varies across the country.

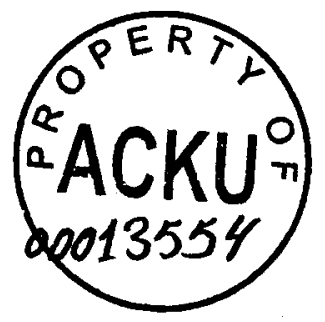

Cover photo by $\mathrm{E}$. Thomson 


\title{
Production and Marketing of Red Meat, Wool, Skins and Hides in Afghanistan
}

\section{A Case Study from Kabul, Kandahar and Kunduz Provinces}

\author{
Euan F. Thomson ${ }^{1}$, Philippe Chabot $^{2}$, and lain A. Wright ${ }^{1}$ \\ ${ }^{1}$ Macaulay Institute \\ Craigiebuckler \\ Aberdeen \\ AB15 8QH \\ United Kingdom \\ ${ }^{2}$ Mercy Corps \\ House No. 558, Street 5, District 10 \\ Qala-e-Fatullah \\ Kabul \\ Afghanistan
}

\[ \text { In association with } \]
Ministry of Agriculture and Animal Husbandry and Food, Afghanistan

November 2005

Funded by the UK Department of International Development as part of the Research on Alternative Livelihoods Fund which is managed by ICARDA

(C) Macaulay Research Consultancy Services and Mercy Corps 
TABLE OF CONTENTS

AUTHORS' PREFACE and ACKNOWLEDGEMENTS

AFFILIATIONS OF AUTHORS and DISCLAIMER

ABBREVIATIONSIACRONYMS, UNITS and EXCHANGE RATES

SUMMARY

CHAPTER 1. INTRODUCTION

CHAPTER 2. A SHORT RETROSPECTIVE OF THE LIVESTOCK SECTOR IN AFGHANISTAN

CHAPTER 3. LIVESTOCK PRODUCTION AND MARKETING FROM THE FARMERS' PERSPECTIVE

CHAPTER 4. LIVESTOCK MARKETING FROM THE TRADERS'

PERSPECTIVE

CHAPTER 5. MARKETING OF NON-EDIBLE LIVESTOCK PRODUCTS

CHAPTER 6. THE FUTURE DEMAND FOR RED MEAT

CHAPTER 7. INCREASING RETURNS TO LIVESTOCK OWNERS

CHAPTER 8. CONCLUDING REMARKS

BIBLIOGRAPHY

ANNEX 1. ESTIMATES OF THE VALUE AND VOLUMES OF BUFFALO IMPORTED INTO KABUL

ANNEX 2. QUESTIONNAIRE USED FOR THE LIVESOCK TRADER SURVEY

ANNEX 3. PRICES OF SKINS, LEATHER, AND FIBRES 


\section{AUTHORS' PREFACE}

This paper reports the findings of project RALF01-09 on 'Marketing of Livestock and Livestock products: Market demand, potential returns to producers and constraints to market access'. It is one of several projects funded through the Research on Alternative Livelihoods Fund (RALF) of the Department for International Development (DFID), London, UK. The RALF programme is managed by the International Center for Agricultural Research in the Dry Areas (ICARDA), Aleppo, Syria.

The overall purpose of the RALF programme is to 'develop and promote innovative alternative livelihood options for rural Afghans currently economically dependent on opium poppy'. The specific goal of this short project was to 'identify market opportunities for livestock and livestock products and constraints to producers receiving higher returns from livestock products' as a viable alternative to poppy growing.

The research on which this paper is based was conducted from November 2004 to March 2005. Preliminary results were presented at a workshop held at the Ministry of Agriculture, Animal Husbandry and Food in Kabul on 17 February 2005 and aspects of the discussion at the workshop have been incorporated into the paper

\section{Euan Thomson \\ Philippe Chabot \\ lain Wright}

November 2005

\section{ACKNOWLEDGEMENTS}

We are are grateful to Mr Ghulam Mustafa Jawad, Deputy Minister at the Afghan MAAHF in Kabul who met with us on several occasions. We thank him for his lively discussions and constructive advice. Mr Jawad and his staff are thanked for facilitating the project workshop held on 17 February 2005.

The staff at Mercy Corps is thanked for providing generous logistical support to the project from its offices in Kabul, Kunduz and Kandahar. In particular, Michael Bowers, Country Director, and Penny Anderson, Programs Director, were always ready to discuss the project and logistical matters. Hayatollah Hayat helped collect data from the livestock markets and traders in Kabul and Hamed Haqpawar spent many hours patiently interpreting during interviews with farmers and traders in the various markets. Engineer Asghar and Atiqullah accompanied Euan Thomson during his visits to Kunduz and Kandahar, respectively, and provided valuable information about the two regions. The efforts of the staff from the Mercy Corps offices in Kandahar and Kunduz who conducted the surveys of market traders are most appreciated.

Several other people are thanked for the valuable information that they provided. Armando Sirolla supplied information about the micro-finance programme of ARMP/AKDN. Amanullah Assil and Andrew Pinney at the VAU (MRRD) helped obtain the price information on sheep in 
the main provincial markets. Raphy Favre kindly provided the information shown in Table 17 .

Finally we are grateful to Mohibullah Halimi, Sayed Agha and Hayatollah Hayat who kindly translated the Executive Summary into Dari and Pashtoo.

\section{AFFILIATIONS OF THE AUTHORS}

Dr Euan Thomson ${ }^{1}$ is an Animal Production Consultant. He was responsible for the aspects of the project related to livestock production, including interviews with farmers and the trading in skins. Philippe Chabot ${ }^{2}$ is an Agricultural Economist who was responsible for the survey of market traders. Dr lain Wright ${ }^{3}$ is an Animal Scientist. He was Principal Investigator of the project and was responsible for the overall coordination and management.

1euan.thomson@talk21.com

2philippechabot@earthlink.net

3i.wright@macaulay.ac.uk

\section{DISCLAIMER}

The views and opinions expressed in this paper are those of the authors and not necessarily of the institutions they represent, of the UK Department for International Development nor the International Centre for Agricultural Research in the Dry Areas. The use of and interpretation of information provided by other persons is the responsibility of the authors of this paper and not of the persons providing the information. 


\section{ABBREVIATIONS / ACRONYMS}

$\begin{array}{ll}\text { AKDN } & \text { Agha Khan Development Network } \\ \text { ARMP } & \text { Afghanistan Rural Micro-Finance Programme } \\ \text { CSO } & \text { Central Statistical Office, Kabul } \\ \text { DFID } & \text { UK Department for International Development } \\ \text { FAO } & \text { Food and Agriculture Organisation of the United Nations, Kabul and Rome } \\ \text { GDP } & \text { Gross Domestic Product } \\ \text { ICARDA } & \text { International Center for Agricultural Research in the Dry Areas, Aleppo, Syria } \\ \text { IFPRI } & \text { International Food Policy Research Institute, Washington DC, USA } \\ \text { MAAH } & \text { Ministry of Agriculture and Animal Husbandry, Kabul (until January 2005) } \\ \text { MAAHF } & \text { Ministry of Agriculture, Animal Husbandry and Food (since January 2005) } \\ \text { MRRD } & \text { Ministry of Rehabilitation and Rural Development, Kabul } \\ \text { NGO } & \text { Non-governmental organisation } \\ \text { NRVA } & \text { National Risk and Vulnerability Assessment } \\ \text { RALF } & \text { Research on Alternative Livelihoods Fund } \\ \text { VAU } & \text { Vulnerability Assessment Unit (a part of MRRD) } \\ \text { WFP } & \text { World Food Programme }\end{array}$

\section{UNITS}

Jerib $=0.2 \mathrm{ha}$

Seer $=7.0 \mathrm{~kg}$

\section{EXCHANGE RATES}

48 Afghanis $($ Afs $)=56$ Pakistani Rupees $($ Rps $)=1$ US\$ 


\section{SUMMARY}

1. High population growth and strong economic recovery since 2002 in Afghanistan is increasing the buying power of urban consumers. One consequence of these changes is a firm demand for meat, particularly in the cities and larger towns. However, as a result of the worst drought in living memory, livestock numbers have decreased dramatically in the last seven years and cheap imported frozen chicken now accounts for almost one-third of the meat sold. One of the challenges facing the national government, assisted by the international community, is to rebuild the Afghan livestock sub-sector to a point where it can once again supply much of the meat consumed in the country and give livestock owners a satisfactory return.

2. In 2004 the area devoted to poppy production reached a record of 131,000 ha and the value of the crop (US $\$ 2.8$ billon) was equivalent to $60 \%$ of the licit national GDP of Afghanistan (US $\$ 4.7$ billion). An estimated 356,000 households, or about one in 10 of the Afghan population, were involved in poppy cultivation. Many of these poppy growers are destitute and landless families that have considerable debts. The Afghan government, with the support of the international community, is therefore giving high priority to the implementation of a strategy that aims to control and eventually eradicate the growing of poppies. A major component of this strategy is to find alternative livelihoods for rural families who are presently growing poppies

3. This paper reports the findings of a short, three-month project to 'identify market opportunities for livestock and livestock products and constraints to producers receiving higher returns from livestock products' as a viable alternative to poppy production. It focused on sheep, goats and cattle and to a lesser extent buffalo, since these aspects received little attention in previous projects. It assessed the strength of the demand for, and the trade in red meat, wool, skins and hides and the main constraints to the participation of farmers in the market for livestock and livestock products.

4. Livestock production and constraints to its expansion were studied in a total of seven villages close to Kunduz and Kandahar, taking account of security considerations and where Mercy Corps could provide logistical support. The areas of poppies in the two provinces were low compared with many of the provinces in Afghanistan but the area is expanding rapidly. Semi-structured interviews were held with groups of farmers in each village. A formal questionnaire was applied in three livestock markets (Kabul, Kunduz and Kandahar) to gather information from a total of 60 livestock traders distributed equally between the three markets. Traders of wool, skins and hides in these three cities were also interviewed as were butchers in Kabul and Kandahar

6. The four villages selected in Kunduz Province have somewhat different farming systems. They included three villages in which irrigated wheat and rice dominated the farming system, with livestock taking a subsidiary place, and one village in which sheep ownership was the dominant livelihood of the families. Only a small proportion of the families in the three villages owned farmland and most of the families derived their livelihood from share cropping and farm labouring. Only 10 to $20 \%$ of the livestock found in the villages in 1995 remained in early 2005 as a result of the severe drought and losses of animals due to nearly 20 years of 
fighting. As a result, more families owned no livestock than 10 years ago. However, because of the large grazing areas, there was considerable scope to restore the contribution of livestock to family livelihoods in two of the villages.

7. The three villages in Kandahar Province have a more homogeneous farming system dominated by irrigated wheat, orchard crops and vegetables. As in other parts of Afghanistan, livestock numbers were much lower than 10 years ago and families owning no livestock were more common. As in the villages in Kunduz Province, families with no farmland depended for their livelihoods on sharecropping and labouring. Compared with the villages in Kunduz Province, there was less scope to increase family incomes by restoring livestock ownership because of competition for grazing resources from the livestock of the nomadic Kuchi that have settled nearby.

8. One or two farmers in most of the seven villages were generating income by finishing lambs (either home bred or purchased) for three or four months on feedstuffs that were locally available. They then marketed these lambs when prices were favourable. Marginover-feed costs for each lamb sold ranged from US\$23 up to US\$70 in some cases. Generally though, farmers were unwilling to purchase lambs for finishing because of the risk of mortality or uncertainly about market prices in the future.

9. The results of the survey of market traders showed that a considerable number of small traders were operating (e.g. 400 in Kabul in any one day) rather than the trade being concentrated in the hands of a few large traders. On a typical day in Kabul and Kandahar each trader was dealing in 22 to 24 sheep and about half as many goats and cattle. Buffaloes were only being traded in Kabul market. Interviews with a few butchers in Kabul found that, on an average day, each one slaughtered about four sheep, one goat and one bovine animal, whereas in Kandahar they were slaughtering lower numbers.

10. Formal-sector marketing expenses and related trader margins comprise between 7 and 16 percent of the wholesale price of sheep indicating that there is little scope for reducing these to reduce marketing chain costs. However, informal expenses, such as bribes, at times comprised an additional 10 to 25 percent of total expenses for livestock marketing. If this could be eliminated the marketing costs would be reduced considerably, and this could result in a significant increase in farm-level prices.

11. Little if any income is generated from the sale of wool since sheep ownership is so much lower than 10 years ago. The small amount of wool collected is used for cushions and mattresses and spun into yarn to make socks, etc. In Kabul wool dealers buy unclean or washed wool and provide employment for several hundred women inside and outside the city who process the wool into yarn. The dealers then sell the yarn to buyers who use it for carpets. Women were also being employed for the same work in Kandahar. Due to the shortfall in domestic wool supplies, uncleaned and cleaned wool is imported at slightly lower prices from Iraq, Iran, Saudi Arabia and other countries in West Asia.

12. Kunduz, Kabul and Kandahar are the major trading centres for the collection of large numbers of raw skins and hides. Nearly all of these products are exported to Pakistan for tanning since there are no tanneries in eastern Afghanistan, apart from some small family 
owned tanneries near Tashkurgon in the north. Thus, Afghanistan is loosing all the valueadded from tanning and production of leather goods. However, it is unclear whether domestic tanneries and manufacturers of leather goods could compete with the industry in Pakistan and with cheap imported leather goods. The handling and storage facilities at the collection points for raw skins and hides are primitive and during the summer this leads to damage to the skins and therefore reduced prices.

13. The main constraint that limits the participation of rural families in the livestock market is either a shortage or a complete lack of livestock. Although livestock numbers are set to recover gradually, at the national level this recovery might take six to eight years in the case of small ruminants and possibly 10 years in the case of cattle. It is the poorest families with just a few or no animals and debts that are the least likely to participate in this recovery and therefore the most likely to work as labourers in the poppy fields. Carefully designed credit schemes linked with restocking with suitable animal species need to be implemented to help lift this vulnerable group out of poverty.

14. Prices for livestock have generally increased over the past few years. At the same time current price levels appear to provide positive incentives for livestock production. Consultations with financial service organizations in Afghanistan indicate that demand for credit for the purchase of livestock is quite high, while loans for livestock in some instances comprise as much as 50 percent of some organizations' total loan portfolio.

15. The estimated current size of the sheep and goat market is US\$130-140 million. The size of this market compares relatively favourably with an estimated value of imported poultry of US $\$ 78$ million and imported buffalo of US $\$ 28$ million. The high estimated income elasticity for demand for mutton coupled with a high growth in per capita GDP suggests that the outlook for demand for mutton over the next five-year period is favourable.

16. Margins from livestock cannot compete with the margins being made from growing poppies. However, the identification and promotion of alternatives sources of income is part of a much wider attempt to curb poppy growing and this study has shown that with a high demand for meat that livestock can play an important part in Afghanistan's agriculture and economy

17. It is concluded that there is considerable scope for the livestock sub-sector to contribute to the economy in Afghanistan. There is a need to design effective restocking schemes with appropriate credit packages. There is also considerable scope to add value to animals by feeding them to higher live weights and selling them at times of the year when prices are high. To achieve this effectively there is a need to provide short term credit, and to conduct on-farm trials with different breeds and diets. 


\section{CHAPTER 1. INTRODUCTION}

One of the consequences of the emerging optimism about the future in Afghanistan is a growing demand for meat associated with the increasing buying power of urban consumers and an expanding population. In the 1970s domestic livestock production supplied most of the market for meat, and livestock played their classical role in rural areas as suppliers of high quality food and as a source of cash, draught power and manure for fuel and fertilizer. The past decade has seen a dramatic crash in the number of livestock due to the worst drought in living memory and the recent conflicts. One consequence of this is the importation of frozen chicken to the main cities (Chemonics, 2004) and of buffalo meat in Kabul. One of the challenges facing the national government assisted by the international community is to rebuild the Afghan livestock sub-sector to a point where it can once again supply most of the meat consumed in the country and give livestock owners a satisfactory return.

Efforts are urgently needed to help Afghan livestock owners participate more effectively in the market. They will thereby derive higher benefits from the growing demand for meat which has in recent years partly been met by imported chicken meat and to a lesser extent buffalo meat. Better incomes from their livestock will also help farmers reduce their dependency on growing opium poppies in areas where there are few alternative sources of livelihood. In 2004 the area of poppies reached a record of 131,000 ha and the value of the crop (US\$2.8 billon) was equivalent to $60 \%$ of the licit national GDP of Afghanistan (US $\$ 4.7$ billion). An estimated 356,000 households, or about one in 10 of the Afghan population were involved in poppy cultivation, worth US\$0.6 billion at the farm level. Many of these poppy growers are destitute and landless families that have considerable debts. The Afghan government, with the support of the international community, is therefore giving high priority to the implementation of a strategy that aims to control and eventually eradicate the growing of poppies. A major component of this strategy is to find alternative livelihoods for rural families who are presently growing poppies.

Higher incomes from livestock will depend on many factors, one of them being more efficient marketing chains which should help ensure that the firm demand for meat is perceived at the farm level. Higher incomes could also result from marketing animals at a higher live weight and at times of the year when prices are higher or adding value to products such as wool.

This paper reports the results of a short project about some aspects of the red meat sector in northern and southern Afghanistan and in Kabul City ${ }^{1}$. The red meat sector has received surprisingly little attention, whereas the dairy and poultry sectors have received considerable donor support over the last 20 years, particularly through FAO and many NGOs. The paper also briefly describes some aspects of the marketing of wool, skins and hides but gives little attention to Karakul pelts and cashmere as they are not important in the study areas. The information presented is based on interviews with livestock owners, a formal survey of livestock traders and interviews with skin/hide and wool traders. The fieldwork took place in

\footnotetext{
${ }^{1}$ In this paper red meat includes mutton (sheep), goat, beef and buffalo meat. The meat of camels and game is not considered even though they are listed in the livestock production data of the 1382 (2003) Afghanistan Statistical Yearbook (CSO, 2003).
} 
Kunduz and Kandahar Provinces and in the cities of Kunduz, Kabul and Kandahar between mid-December 2004 and mid-February 2005.

The aim of the project was to 'identify market opportunities for livestock and livestock products and constraints to producers receiving higher returns from livestock products' as a viable alternative to poppy production. It assessed the strength of the demand for and the trade in red meat, wool, skins and hides and the major constraints to participation of farmers in the market for livestock and livestock products. At the local level the project focussed in areas and villages where Mercy Corps has been operating for some time. The situation in key local markets was studied and barriers to the efficient operation of these markets identified. Forecasts are presented of the potential future demand for mutton in particular and recommendations made on how to improve marketing chains and the exchange of price and demand information so that producers receive a higher percentage of the retail price. 


\section{CHAPTER 2. A SHORT RETROSPECTIVE OF THE LIVESTOCK SECTOR IN AFGHANISTAN}

In the 1960s and 1970s the livestock sub-sector was a significant component of the largely agrarian and pastoral economy of Afghanistan, with about $85 \%$ of the rural population being dependent on agriculture as their main livelihood. A large population of cattle, sheep, goats, camels and poultry produced sufficient meat to supply the human population (Table 1). Indeed, in the 1970s Afghanistan possibly exported approximately one million sheep to some of its neighbours, mainly Iran, and unknown numbers of other livestock species. Exports of commodities derived from livestock were also significant.

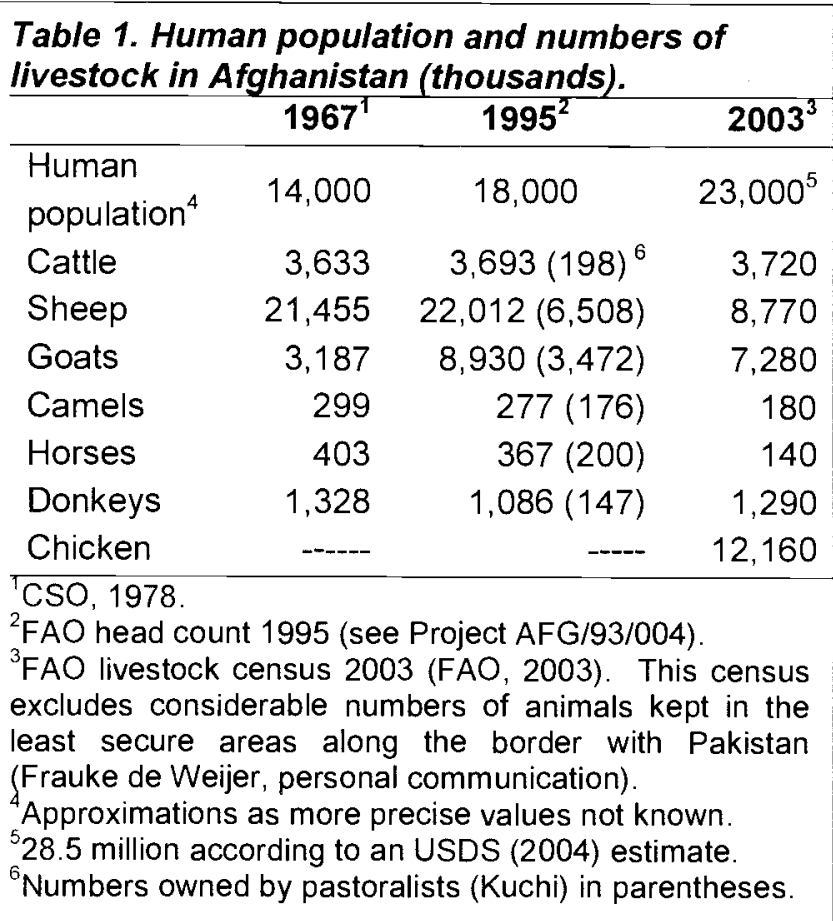

Barfield (2004) cites data from Dupree (1973) and Fry (1974) showing that exports from the pastoral economy (carpets, rugs, casings for sausages, wool, Karakul pelts, hides, skins) in $1969 / 70$ accounted for about $43 \%$ of total agricultural exports, which reached US\$69 million that year. Khan and lqbal (1999) cite a World Bank report (World Bank, 1979) which valued unrecorded exports of live sheep to Iran in 1976/77 at US\$33 million.

Ford (1986, page 190) reported total annual consumption of different meats in Afghanistan to be $11.5 \mathrm{~kg}$ per capita, a value probably taken from the study for USAID of Hakimi (1976) covering the years $1957 / 58$ to $1976 / 77^{2}$. As shown later in this paper, consumption today appears to be much lower. Until the mid-1990s livestock numbers were still high enough to allow exports to Iran and Pakistan, despite the upheavals of war with the Soviet Union during the 1980s and civil war between different factions of the Muhajaddin in the early 1990s. Numbers remained high until mid-1999 when the first effects of the drought started to be noticed following the winter and spring of 1998/99 when precipitation was well below average. During the ensuing three years destitute farmers and nomads slaughtered or sold huge numbers of their animals in order to raise cash to buy food. Large numbers of livestock also died from emaciation, thirst and disease. The better precipitation of the winter/spring of $2002 / 03$ in the north and east of the country eased the problems somewhat, but the drought continued until the end of 2004 in the south and west of Afghanistan where by early 2005 there had been good rainfall.

\footnotetext{
${ }^{2}$ A value of about $14.5 \mathrm{~kg}$ red meat per capita depending on the human population used can be derived using FAOSTAT data for the 1970s.
} 
The national livestock census in 2003, the first for 36 years ${ }^{3}$, showed that family ownership of cattle, sheep and goats had decreased by $67 \%, 87 \%$ and $74 \%$ respectively since 1995 (FAO, 2003). Included in these percentages are a large number of settled families who used to own a few livestock in the mid-1990s but owned none in 2003. The Kuchi nomads, who according to some sources, previously owned one-third to half of the sheep and goats in Afghanistan (Thieme, 1996), suffered as well, with family flocks of several hundred head gradually dwindling to just a few or none at all over a four-year period ${ }^{4}$.

Sheep numbers were particularly reduced during the drought and therefore estimated outputs of sheep and goat milk and meat were more affected than meat and milk production from cattle (Table 2). These values compare with the nearly 50,000 tonnes of frozen chicken that were imported into Afghanistan in 2003/04 (Chemonics, 2004), about half of which was sold in Kabul. Such imports started in 2002. In other words imported frozen chicken accounts for almost as much meat as domestic production of mutton and goat meat and more than domestic beef production. In addition, live buffaloes imported from Pakistan and marketed in Kabul supply up to 6,000 tonnes of meat ${ }^{5}$. Five years

Table 2. Estimated' outputs of livestock products in 1995/96 and 2003.

\begin{tabular}{llrr} 
Product & & $\mathbf{9 5 / 9 6}$ & $\mathbf{2 0 0 3}$ \\
\cline { 3 - 4 } Milk & Cattle & 638 & 637 \\
('000 t) & Sheep/goats ${ }^{2}$ & 624 & 325 \\
Meat & Beef & 43 & 43 \\
('O00 t) & Mutton/goat & 104 & 54 \\
Eggs & Number (million) & 350 & 304 \\
& Wool & 33 & 13 \\
Non- & Goat hair ('OOOt) & 4.5 & 4.0 \\
edible & Cashmere ('OOOt) & 0.3 & $0.2^{3}$ \\
products & Pelts (thousands) & 450 & 200 \\
& Hides (thousands) & 450 & 455 \\
& Skins (thousands) & 6,500 & 3,370
\end{tabular}

${ }^{\top}$ Based on offtakes of Thieme (1996, page 25) and livestock populations from the $2003 \mathrm{FAO}$ census (FAO, 2003) (see Table 1).

${ }^{2}$ The two estimates are high because ewes are assumed to yield $40 \mathrm{~kg}$ milk per lactation.

${ }^{3} \mathrm{~A}$ recent study (Altai Consulting, 2005) estimated current exports of cashmere from Afghanistan at 1,000 tonnes/annum. ago very few buffalo were being imported into Kabul. The sheep losses due to the drought also explain the lower wool, pelt and skin production in 2003 than in 1995/96.

Since January 2003 prices of one-year-old rams averaged across the markets in Mazar-eSharif ${ }^{6}$, Kabul and Kandahar increased by $48 \%$ over 28 months $^{7}$ but the patterns in each market are different and difficult to interpret (Figure 1$)^{8}$. In the south, which was affected by drought until late 2004, prices were lower in January 2003 than in the other two markets and then increased quickly before stabilizing. Prices started higher in Mazar-e-Sharif and Kabul than in Kandahar and gradually increased until the summer of 2004 when they showed sharp

\footnotetext{
${ }^{3}$ The last one was in 1967 (see Thieme, 1996, page 6).

${ }^{4}$ The kuchi suffered enormous hardship as a result of the drought. More information can be found in papers by De Weiger (2002) and Jost (2004).

5 Based on information collected at separate interviews in Tai Maskin livestock market (see Annex 1).

${ }_{7}^{6}$ Monthly prices were not being collected in Kunduz and therefore prices in Mazar are used instead.

${ }^{7}$ Based on the percentage increase of the price averaged over April, May and June 2005 compared to the price averaged over January, February and March 2003.

${ }^{8}$ Prices of food commodities including sheep are being collected by different agencies and compiled by the Vulnerability Analysis Unit at the MRRD
} 
drops at different times before recovering again. Information is not available to help explain these sharp drops but they result in a flattening of prices in the summer of 2004 . The breaking of the drought in the north two years earlier than in the south is a possible explanation for the smaller price increases over 28 months in the north $(16 \%)$ than in the south $(81 \%)$.

Without a clear understanding about the situation it is difficult to explain the price recovery in Kabul which was $60 \%$ over 28 months. Rising household incomes could be one factor leading to an improved demand for red meat. For example, Kabul has the highest concentration of 'middle-to-high' income families in the country and they are undoubtedly helping to drive the rapid economic growth seen across the country. The demand for mutton, which was selling for about US $\$ 4$ per $\mathrm{kg}$ in January 2005 , is partly mitigated by the lower price of buffalo meat which was about US\$3 per $\mathrm{kg}^{9}$. The current rapid increase in the population of the city is a less plausible explanation for the increasing mutton prices since it is the poorest incomes groups (returning refugees and internally displaced persons seeking work) that account for much of the population increase. This income-group, if they can afford to buy meat at all, would most likely buy the cheapest meat (imported frozen chicken legs) which in January 2005 were selling at about US\$1.5 per $\mathrm{kg}$ as compared with nearly US\$4 per $\mathrm{kg}$ for mutton with bones.

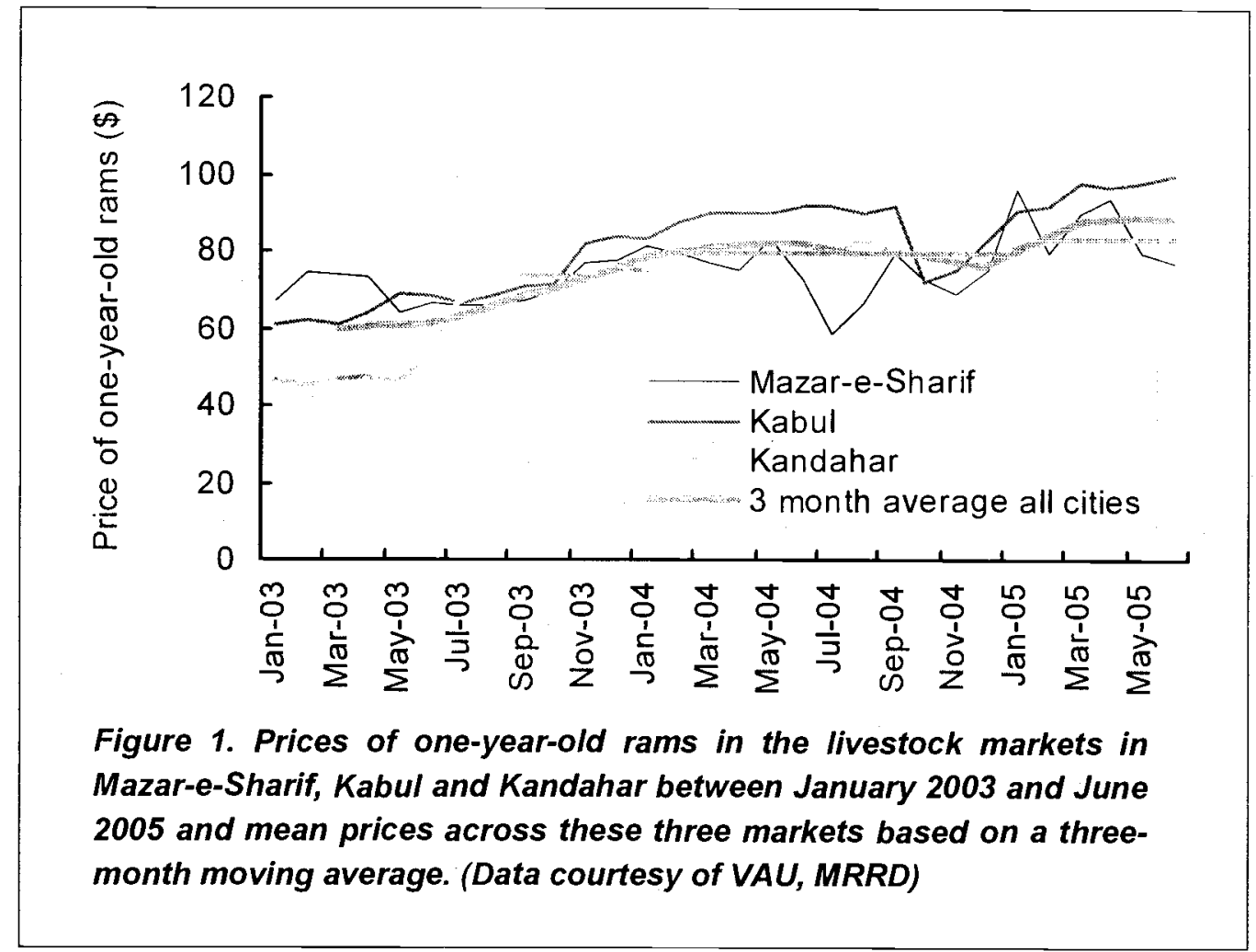

\footnotetext{
${ }^{9}$ Mutton and goat meat is sold with the bone whereas most beef and buffalo meat is sold without the bone. However, pieces of backbone are often included, particularly if it is the meat of a young animal.
} 


\section{CHAPTER 3. LIVESTOCK PRODUCTION AND MARKETING FROM THE FARMERS' PERSPECTIVE}

\section{Introduction}

This chapter describes the fieldwork that was conducted in a number of villages to identify the constraints that limit the returns of farmers when they market livestock and livestock products. The scope to increase family income by selling more and better finished live animals is also examined. The chapter starts with an outline of the methodology applied during the fieldwork, and then presents the findings from that fieldwork.

\section{Study methods}

Provinces were selected for the fieldwork where Mercy Corps could provide logistical support, rather than on the basis of the areas of poppies grown in previous years. Indeed, Kunduz and Takkar Provinces in the north have modest areas but there appears to be a rapid increase in the area. Kandahar Province has a moderate area of poppy cultivation (Table 3).

A total of seven villages were visited (Table 4). Because of the better security in Kunduz Province there was more flexibility to select villages with contrasting production systems. The knowledge of Mercy Corps staff was used to select four villages which show a large variation in the contribution of livestock to the

\begin{tabular}{lccc}
\multicolumn{4}{l}{ Table 3. Areas (ha) of poppy grown in } \\
recent years. (Source: UNODC, & 2004). \\
\hline Province & $\mathbf{2 0 0 2}$ & $\mathbf{2 0 0 3}$ & $\mathbf{2 0 0 4}$ \\
\hline Kunduz & 16 & 49 & 224 \\
Takkar & 788 & 380 & 762 \\
Kandahar & 3,970 & 3,055 & 4,959 \\
Total area in & 70,000 & 80,000 & 131,000 \\
Afghanistan & & &
\end{tabular}
livelihoods of the people ${ }^{10}$. In Kandahar Province security considerations necessitated selecting three villages in which Mercy Corps was working, or those nearby. The three villages have farming production systems based on field and orchard crops and some livestock $^{11}$. Information in the UNODC (2004) report suggests that poppies were grown in 2004 in all the districts in which the seven villages are situated but the actual areas grown in the villages is not known. The total area of poppies grown in Kunduz Province increased from 16 to 49 ha between 2002 and 2003 and in Kandahar Province it decreased from 3,970 to 3,055 ha (UNODC, 2004, Annex 1). The interviews were conducted by a team comprising the researcher responsible for this part of the project (Euan Thomson), an interpreter, a member of Mercy Corps staff with experience of the area and, in Kunduz and Takkar, a representative of the MAAHF.

Information was gathered at group interviews. A checklist was used to guide the group interviews which were attended by between six and 30 farmers. Particular attention was given to collecting information about changes in livestock ownership of individual families

\footnotetext{
${ }^{10} \mathrm{~A}$ fifth village was visited in Chardara District to the west of Kunduz City but it was found that the farmers present at the interview were from several different villages which made it difficult to discuss individual sheep ownership.

${ }^{11} \mathrm{~A}$ fourth village was visited but focusing the interview with the settled farmers was complicated by the presence of several Kuchi livestock owners who were keen to be interviewed as well.
} 
over the last 10 years. A total of nine group interviews were held in late January and early February 2005. At three of these, farmers were present who were willing to give detailed information about the numbers of livestock that they owned at present and in 1995. The interviews also gave attention to the practices used by farmers to grow and finish sheep, attitudes towards different species of livestock, the financing of restocking schemes and adding more value to sheep sold in local markets.

\section{The farming systems in the five villages}

The relative importance of crops, fruit trees and livestock in the seven villages visited are shown in Table 4. Aq Masjeed village has a farming system dominated by crops and livestock are a small component of the system. The village lies on the fertile plain of the Taloqan River. It has about 80 families and only 25 jeribs of cultivated land which is owned by five or six families. Most of the remaining families are sharecroppers. The main crops are irrigated wheat and rice but vegetables such as carrots, onions, tomatoes, melons and small areas of barley and other forage crops (alfalfa and Persian clover - Trifolium resupinatum)

Table 4. The seven villages visited in the two provinces and the current contribution of crops, fruit trees and livestock to livelihoods.

\begin{tabular}{|c|c|c|c|}
\hline $\begin{array}{l}\text { Name of } \\
\text { village }\end{array}$ & Crops & $\begin{array}{l}\text { Fruit } \\
\text { trees }\end{array}$ & $\begin{array}{l}\text { Live- } \\
\text { stock }\end{array}$ \\
\hline \multicolumn{4}{|c|}{ Kunduz Province } \\
\hline Aq Masjeed & High & Low & Low \\
\hline Baloch & Low & Low & High \\
\hline Saqab $^{1}$ & High & Low & Low \\
\hline Choghesufula & High & Low & Medium \\
\hline \multicolumn{4}{|c|}{ Kandahar Province } \\
\hline Sardeh & High & Medium & Low \\
\hline M. Yakoub & High & Medium & Low \\
\hline Shirandam & High & Low & Medium \\
\hline
\end{tabular}
are also grown. In January 2005 most of the 80 or so families in the village owned one or two cows but no sheep or goats. Despite the relative proximity of Kunduz, a major problem is the lack of work for the men who are unemployed for much of the year.

The five farmers present at the interview in Aq Masjeed owned, respectively, one ox, one cow, three cows, three oxen and five cows. The last farmer owned the highest number of animals in the village. Ten years ago there were more cattle in the village and some sheep, with a few families owning $10-15$ head. Numbers decreased because of the fighting when families abandoned their houses and livestock, and more recently because of the drought. Now that there is better security in the area families are trying to increase the number of livestock, particularly cows. Each family would like to own a few sheep and goats but numbers would remain low because there is no grazing in the intensively cultivated valley. 





In Baloch village sheep ownership is the main livelihood of the inhabitants. The village lies on the north bank of the Taloqan River which forms the natural boundary between the fertile plains to the south, dominated by irrigated wheat and rice production, and a large area of semi-desert (dasht) to the north. As the name suggests, the village is inhabited by people of the Baloch tribe that is mainly found in western Balochistan, the province in south-west Pakistan, and across the border in eastern Iran and southern Afghanistan. It is a large village with about 600 households and approximately 25,000 sheep, or about 40 per household. Many of the households also own a few goats.

In the past the sheep owners in Baloch practised transhumance, with the sheep moving in spring to the mountain pastures to the east in Badakhshan Province where they remained for three months. At interview (attended by about 30 farmers), there was general agreement that numbers were higher 25 years ago. One older farmer claimed that at that time his father owned 2,500 head but today there are only 200 head left, distributed among 10 brothers. At a follow up interview to gather more information, a smaller group of farmers willingly provided the numbers of livestock that they owned. Numbers were substantially down compared to the mid-1990s. Fighting in the region during the 1980 s and the 1990 s resulted in large numbers of sheep being stolen by rival armies when the flocks were moved during the spring and autumn migrations. Losses also resulted from diseases and starvation, particularly during the recent drought.

A crop-dominated farming system is found in Saqab village in Takkar Province (Bangi District), but because of the extensive grazing areas there is considerable scope to rebuild the livestock component of the system. The village has about 100 households and the 200 jerib of irrigated $(a r b i)$ arable land is used in summer to grow rice, maize, cotton and vegetables while winter wheat is grown in winter. Some irrigated alfalfa is also grown for feeding to cattle. An additional 1,000 jerib of rainfed (lalmi) land is located on the hills that border the fertile plane. Wheat is grown on these lands in winter and melons, chickpeas and flax in summer. The hills also provide a large area of grazing. One quarter of the families have no arable land and half of the families in the village owned no livestock. Farmers were unable to say how many families owned neither land nor livestock. There were said to be about 50 cattle of different ages in the village, down from about 400 head in 1995. There were an estimated 30 sheep and 70 goats in the village, down from 200 and 700, respectively, in 1995 . These large decreases were mainly due to the theft and slaughter of animals during the fighting that raged across the region in the 1980s and 1990s.

The farming system in Choghesufula village has many similarities with Saqab. The village has about 75 households, 250 jeribs of irrigated land and 800 jeribs of rainfed land. The same crops were grown as in Saqab, but yields were lower than 10 years ago because of the lack of inputs and good seed. However, only about half of the families 
owned arable land and many of the landless families were either sharecroppers or they worked as farm labourers. In contrast to Saqab, in January 2005, 80 to 90 percent of the families still owned livestock and there were said to be 600 cattle which included many oxen, 1,000 sheep and 200 goats. Despite these numbers, farmers claimed that livelihoods were more dependent on the income from crops or farm labouring than from livestock. Indeed, livestock numbers were possibly 10 percent of what they were 10 years ago as a result of the fierce fighting between Taleban and Northern Alliance forces in the late 1990s and early 2000s. During the last three years security in the area has improved and crops were again being grown on the rolling hills, although in some places mines remained a serious hazard.

Table 5. Farming systems in the three villages visited close to Kandahar city. Sardeh Mohammed Shirandam Yakoub

\begin{tabular}{|c|c|c|c|}
\hline Number of families & 35 & 100 & 400 \\
\hline Crop area (jerib) & 200 & 200 & 2,300 \\
\hline Orchard area (jérib) & 150 & 100 & 1,200 \\
\hline Families with cultivable land (\%) & 33 & 20 & 50 \\
\hline Families with livestock (\%) & -1 & 70 & 50 \\
\hline Main field crops & \multirow{6}{*}{\multicolumn{3}{|c|}{$\begin{array}{c}\text { Wheat, barley, maize, mung beans, groundnut } \\
\text { Melons, ochra, onion, cucumber, tomatoes } \\
\text { Pomegranates, plums, grapes } \\
\text { Alfalfa } \\
\text { Share-cropping, farm labouring, manual } \\
\text { labouring ( } \$ 3 / \text { day) } \\
\text { Available, but poor quality and competition with } \\
\text { Kuchi herds }\end{array}$}} \\
\hline Main vegetable crops & & & \\
\hline Main orchard crops & & & \\
\hline Main forage crops & & & \\
\hline Other sources of income & & & \\
\hline Grazing area & & & \\
\hline \multicolumn{4}{|l|}{ Livestock ownership in village ${ }^{2}$ : } \\
\hline - Cows (per household) & 1 or 2 & 1 or 2 & 1 or 2 \\
\hline - Sheep (total in village) & $100-150$ & 150 & $150-200$ \\
\hline - Goats (total in village) & 30 & 200 & 0 \\
\hline
\end{tabular}

The three villages visited in the south of Afghanistan are located within $15 \mathrm{~km}$ of Kandahar city. Annual crops and orchards dominate the farming systems although livestock could again contribute substantially to the families' livelihoods once numbers recover (Table 5). The number of families in the three villages varied considerably but only 20 to 50 percent of them actually owned cultivable land. Many of the families owning no land owned a few livestock but it was not possible to ascertain what percentage owned no cultivable land or no livestock. Many of the families depended on sharecropping, farm labouring and manual work in Kandahar as their main source of income. Men in Shirandam earned US\$3 a day to break stones in a nearby quarry. The same field, vegetable, orchards and forage crops were grown in each village. The area 
of alfalfa on a farm varied considerably, from none to two or three jeribs depending on the availability of land and water. It was generally cut and carried to tethered or housed cows but in Shirandam a few farmers made modest earnings from selling alfalfa in Kandahar city. Fresh alfalfa sold for US\$0.038/kg in summer when supplies are abundant and $\$ 0.06 / \mathrm{kg}$ in autumn when the supply is limited.

The drought, which started in the winter of 1998/99 and appeared to have ended in the winter of 2004/05, was given as the main reason for the large reductions in livestock numbers due to deaths and emergency sales. Ten years ago there were approximately 2,500 - 3,000 sheep in Shirandam and the cows from each family were gathered together each day in one herd and taken to the grazing areas. Numbers decreased steeply because of the fighting and drought. The drought has also caused a reduction in the quality of the grazing in the surrounding plains and hills and there continues to be increased competition for the remaining grazing from the animals belonging to the Kuchi that now camp permanently close to the villages. In Sardeh the absence of oxen forced farmers to pay US $\$ 7$ per hour to hire a tractor. They would like to own oxen again because they believe tractors cause compaction of the soil. Moreover, an ox can be sold at any time to raise cash when other sources of cash are not available.

\section{Livestock feeding practices and income generation from livestock}

Farmers in Al Masjeed bought cottonseed cake (CSC, kunjara) in Kunduz where the long-established Spinzar cotton ginning plant is located. After being idle for many years, due to damage caused during the fighting, foreign assistance had enabled it to start operating again. This, together with the increasing area of cotton being grown in Kunduz Province, should increase the supplies of CSC which presently costs US $\$ 240 /$ tonne. Farmers feed it to cows in winter to supplement the basal diet of wheat straw. In the autumn of 2004 one of the farmers interviewed purchased $280 \mathrm{~kg} \mathrm{CSC}$ to feed to his two working oxen but his stocks were low and he could not afford to purchase more at a critical time when the animals were needed for ploughing. Older oxen that no long work were sometimes fed some CSC in order to add some weight and therefore earn a higher price at sale. Rice straw is sometimes fed to livestock but because it is of low feeding value and the shortage of fuel, most of it is used for heating and baking.

In winter the sheep in Baloch graze in the nearby semi-desert and are supplemented with CSC, cottonseed hulls (CSH), barley grain and some wheat straw. It costs about 1,000 Afs (US $\$ 21$ ) to feed a ewe through winter. The fat-rumped Turki breed, which is common across north-east Afghanistan and into Tajikistan, is well suited to feeding practices which exploit the good growth potential of the breed after weaning. Lambing rate averages 70 to 80 lambs born to 100 ewes exposed to rams and the twinning rate is low, sometimes as low as $10 \%$. 
In Baloch village most of the ram lambs are sold in Kunduz market in September (Mizan) each year. This is the usual practice in the region because farmers often have debts from the previous winter and they are unable to afford to feed the lambs through the coming winter. The glut of lambs depresses prices in autumn. In September 2004 the price was about US $\$ 60$ for five-to-eight month-old ram lambs weighing 18 to $20 \mathrm{~kg}$. Female lambs are retained as replacement stock and to restore flock numbers. Traders who buy the ram lambs transport them to Kabul and Mazar-e-Sharif where the larger lambs are sold to butchers. Smaller lambs are sold to other farmers who feed them for a few months to increase their weight and sell them when prices are higher.

Only one of the 15 farmers present at the second interview in Baloch village was exploiting the opportunity to generate more income by growing and finishing ${ }^{12}$ some lambs, to take advantage of the higher prices prior of the Eid-al-Adha festival which occurred in mid-January in 2005. Instead of selling lambs in autumn, when they were worth about US\$60, he kept six of his ram lambs, fed them for four months and sold them just before the Eid for US\$165 each. The feeding costs to buy CSC, CSH and barley grain to supplement the purchased wheat straw, were about US $\$ 30$ per lamb. The farmer explained that he had added about US $\$ 75$ to the value of each lamb by feeding it for four months. The other farmers present at the interview said they would need a loan to buy the feed for the lambs and were not prepared to take the risk because some lambs might die or would not grow well. However, the suggestion to make short-term loans available to finance the purchase of feeds, in order to add value to lambs, generated considerable interest.

One farmer in Sardeh village near Kandahar generated income from buying, fattening and selling sheep. He had recently paid about US $\$ 1,600$ for 15 sheep but two of them had already died. Such losses help explain why many farmers are unwilling to risk their savings in this way. The farmer's remaining 13 animals needed $135 \mathrm{~kg}$ maize grain and $225 \mathrm{~kg}$ wheat straw each month, at a cost of about US\$4 per lamb per month. As he would keep them for about four months and expected to make a profit of about US $\$ 30$ per sheep, he would have to sell each one for about US\$165, the same price as the farmer in Baloch village sold his ram lambs for. Another five farmers in village were fattening sheep and, despite the risks, more said they would do so if they had the savings.

\footnotetext{
12 The terms growing and finishing are used somewhat loosely in this paper because some experts find the term "fattening" inappropriate due to the "Western" perception that associates the consumption of saturated fats that are present in beef, mutton, milk and dairy products with coronary heart disease. When farmers exploit market opportunities such as the higher livestock prices prior to the Eid-al-Adha, the older rams they are selling have been fattened to add finish to them. As the survey of four butchers in both Kabul and Kandahar showed, urban consumers still prefer mutton to goat meat since it is tastier and more succulent. The high price of pure fat from the fat tail of sheep shows that consumers value this product as much as the lean meat.
} 
However, finishing lambs was common in Mohammed Yaqoub. One farmer purchased 11 sheep for about US $\$ 890$ in the autumn of 2004 , fed them for four months and sold them before the Eid-al-Adha in mid-January 2005 for about US $\$ 1,070$. They were fed on fresh alfalfa from his own field and maize grain which he purchased. He expected to make a profit of about US\$15 from each lamb sold.

Families generally fatten one or two sheep when preparing for weddings and religious occasions. But one farmer in Shirandam had purchased 25, nine-month-old male lambs in the autumn of 2004 directly from some Kuchi. This circumvents paying any market taxes or fees and results in a low purchase price, US\$54 for each lamb in this case ${ }^{13}$. Three months later the farmer sold each lamb for about US\$107 before Eid-al-Adha although those that were sick sold for US\$70. The lambs weighed about $13 \mathrm{~kg}$ at purchase and about $30 \mathrm{~kg}$ at sale. After deducting feed costs - maize grain and wheat straw - the profit was about US $\$ 18$ for each lamb sold. Another farmer also estimated his profit at about US $\$ 18$ for each of the 10 sheep that he had feed and sold when prices were favourable.

\section{Problems facing livestock farmers, including marketing issues}

The fighting in Afghanistan had a traumatic effect on both the urban and rural population over a 20-year period and this was followed by the worst drought in living memory. The most obvious effect of the drought was a huge reduction in the livestock numbers as compared with 1995. The information shown in Figure 2 illustrates this point. It was obtained by asking individual farmers at the interviews in three of the nine villages about their household ownership of cattle, sheep and goats.

When expressed as percentages these reductions are similar to those reported in the ICARDA survey in 2002 which sampled 187 villages and the 2003 FAO census which sampled over 36,724 villages (Table 6 ). Despite the huge differences in the size of the samples, the ranking of the losses among the three livestock species is consistent across the three studies. These results are not necessarily evidence

Table 6. Percentage reductions in the numbers of livestock in three villages between 1995 and 2005, as compared with data from the ICARDA 2002 survey and the FAO 2003 census.

\begin{tabular}{lccc}
\hline & $\begin{array}{c}\text { Present } \\
\text { study }\end{array}$ & $\begin{array}{c}\text { ICARDA } \\
\mathbf{2 0 0 2}^{\mathbf{1}}\end{array}$ & $\begin{array}{c}\text { FAO } \\
\mathbf{2 0 0 3}^{\mathbf{2}}\end{array}$ \\
\hline Cattle & 76 & 70 & 67 \\
Sheep & 90 & 77 & 87 \\
Goats & 85 & 72 & 74 \\
\hline
\end{tabular}

${ }^{1}$ Estimated over four years, $1998-2002$.

${ }^{2}$ Estimated over eight years, $1995-2003$. that sheep are the most susceptible livestock in a drought situation. A more likely explanation is that they were the most numerous livestock in the mid-1995s and have a

${ }^{13}$ Uncastrated ram lambs among the batch were castrated as farmers believe castrates grow faster and that consumers prefer mutton with a milder flavour. 
higher market value than goats. For these reasons they were the first to be used for emergency sales. Furthermore, in large flocks sheep are likely to be the first livestock to be neglected in a drought situation, with the family cow being sold as a last resort because it supplies milk and milk products with a high nutritional value to children.

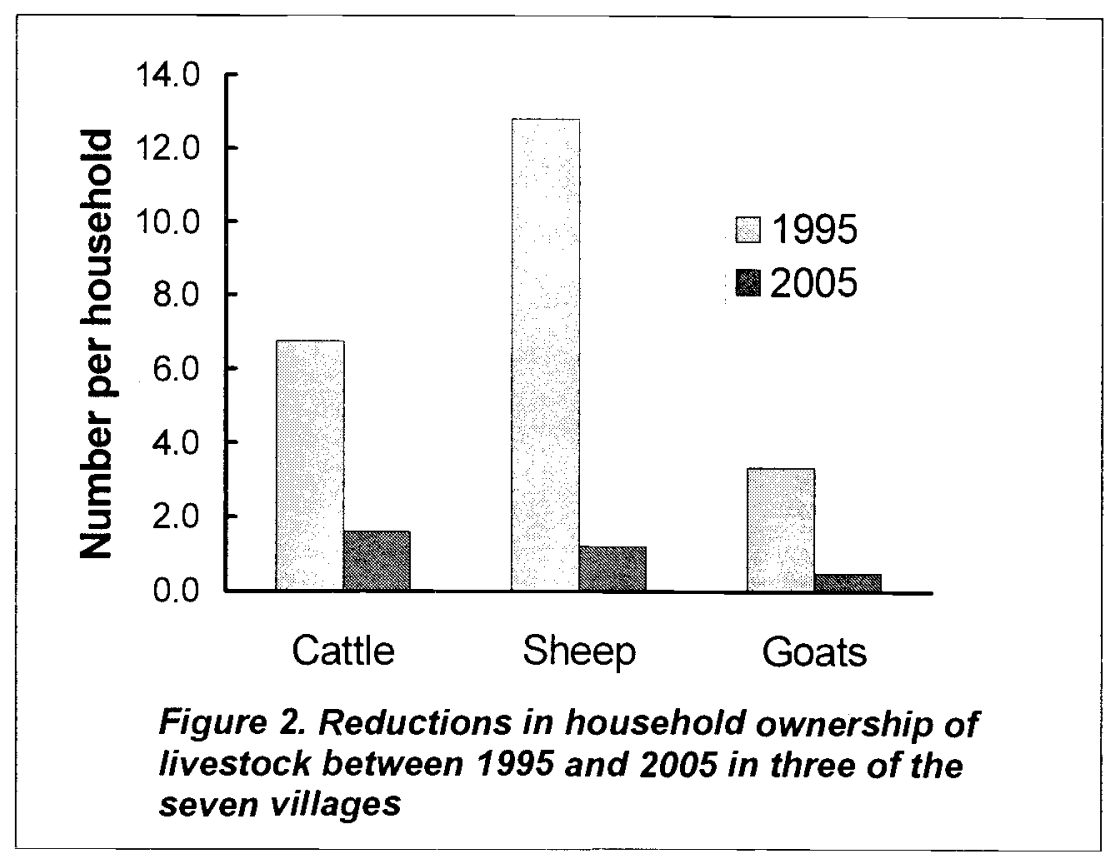

Farmers were aware of the seasonal variations in the prices of animals. For example, in the south of Afghanistan prices of cows are high in spring because cows are generally in early lactation. Prices decrease in summer because feed costs are low and demand for meat falls, since people eat more of the plentiful and cheap vegetables. In the autumn and the beginning of winter prices of meat and vegetables increase again since urban consumers start eating more meat and fewer vegetables are available. But most of the farmers were not able to exploit these market opportunities, such as better prices in winter and spring. This is because they had debts to pay off, often a consequence of the drought which resulted in failed crops, or they had to make distress sales of animals at times when prices were low.

The farmers in Al Masjeed village did not identify any particular marketing problems because Kunduz was $10 \mathrm{~km}$ from the village, and therefore within walking distance. Indeed, they preferred to sell animals there since they could bargain with a number of traders and therefore earned 5 to $10 \%$ more than they would if they sold animals to 
traders who came to the village ${ }^{14}$. Moreover, by walking the animals to market they avoided paying transport costs. During the last 12 months, of the five farmers present at the interview who owned nine cows between them, only the farmer owning five cows, the largest herd in the village, had sold a two-year-old calf for US $\$ 300$. Thus, the offtake from these herds during the last 12 months at least was very low.

Farmers in Baloch village were asked about the main problems that they faced in general. The foremost problem was a lack of feed, the second a lack of water in the desert and the third the animal losses that they had suffered in the past when moving their animals to and from the summer pastures in Badakhshan Province. They complained about a shortage of CSC and CSH although the area of cotton grown in Kunduz Province in 2004 had recovered to about $60 \%$ of the area grown during the 1970s. The price of CSC had recently increased substantially since the Spinzar plant in Kunduz had become a subsidiary of a foreign company. Significantly, the farmers faced no particular difficulties when selling their animals in Kunduz market. If prices were not high enough to make a reasonable profit, farmers would walk their animals back to the village. The improved security over the last three years was enabling some of the farmers to restock their flocks, in some cases financed by the remittances sent by sons working in other countries.

The marketing of livestock was of limited relevance in Saqab since animal numbers were down drastically as compared with 1995. Apart from the farmer currently owning the most livestock who remained in the village throughout the Taleban years, the others lost everything when they fled with their families to Pakistan and Iran when the fighting started. They returned to the village in 2002 after the collapse of the Taleban in late 2001.

The largest sheep owner in Cholgesufulah who happened to be present at the interview showed his entrepreneurial skill but also the risks (see Box 1). He owned 20 cattle and 250 small ruminants whereas in 1995 he had owned 35 cattle and 700 small ruminants. His total sales in 2004 were about 75 small ruminants. The feed and other costs of keeping a sheep for finishing over four months totalled US\$42. They need about $210 \mathrm{~kg}$ of feed, composed of 'green' straw from mung beans, barley grain, CSC and wheat straw $^{15}$. However, such practices were uncommon in Cholgesufulah because farmers could not afford the initial expenditure on feed and then wait four-months to realise their investment. Animals were usually sold in the village as the prices were similar to those in Khanabad market and selling to traders who came to the village saved walking the animals to the local market.

\footnotetext{
${ }^{14}$ During an informal visit to two villages close to Kabul, farmers preferred to sell directly to butchers coming to the village rather than to traders because the butchers offered a higher price. This avoided the cost of transporting the animals to Kabul's main markets and the pressures from many traders to accept a low price.

${ }^{15} 210 \mathrm{~kg}$ (30 seers) of feed spread over 120 days is equivalent to about $1.75 \mathrm{~kg}$ per day which a sheep could consume. The daily feed cost for a sheep is about $\$ 0.35$ at a cost of about $\$ 210 /$ tonne.
} 
Animals from the three villages visited in the south are mainly sold in Kandahar market which is 10 to $15 \mathrm{~km}$ away. Sometimes farmers in Sardeh walked their animals to market. This took 2 to 4 hours but it saved the trucking cost of about US\$10 for a cow and about US\$0.4 for a sheep. The headage fee to enter the market was reported to be about US $\$ 0.60$ for cattle and about US $\$ 0.20$ for a sheep or goat. Farmers complained that the official fees are not published which resulted in over-charging.

\section{Preferences for different livestock species}

The priority given by farmers to different species of livestock varied from one location to another and needs to be taken into account if restocking schemes are considered $^{16}$. For example, in Aq Masjeed cows were preferred because there was no common grazing and Kunduz city was close enough for families to sell yoghurt. But, as would be expected, in Baloch, sheep were preferred since there was a lack of feed for cows and oxen were not needed since there was no arable land to cultivate. The farmers were interested in a loan scheme to enable them to fatten lambs, and were willing to pay interest on the loan.

The farmers in Saqab were inconsistent in their preference for different livestock species. To some extent they preferred to restock with sheep rather than goats, since sheep were more docile, which makes them easier to herd, and they

\section{Box 1. Advantages and risks of entrepreneurialship.}

A farmer in Kunduz Province demonstrated his awareness of prices in different parts of eastern Afghanistan. In 2004 he hired two trucks and transported about 40 sheep several hundred kilometres to Kabul. The better prices there gave him a higher profit than selling in the local market, even after paying the transport costs. However, the buyer in Kabul defaulted on the 80,000 Afs debt that he owed the farmer who was unable to recover it, even though he took the trader to court. He said the court was biased in favour of the trader. earned more at sale. But sheep need more winter feed than goats and farmers therefore had to purchase 'green straw' from mung beans and hay made from an unidentified plant that grows on rangelands in the central and northern areas, known locally as yantak. However, in the past, goats were more popular since they were cheaper to keep, better at walking in the hills and could even be left to go to the hills in the morning and return in the evening without a herder. A herd of 50 goats owned by one family would fend for themselves, whereas five cows would be too many as they needed to be stall-fed for much of the year. In general the farmers were interested in a goat-lending scheme, mainly because does have a higher fertility resulting in numbers recovering faster. This is similar to findings in Kazakhstan in recent years (C. Kerven,

\footnotetext{
${ }^{16}$ Women often give livestock a different priority than men. For example, they might prefer to own a cow or goats because the milk the livestock provide can be fed to children. Certainly women's views should be taken into account when designing restocking schemes.
} 
personal communication) where, after a dramatic crash in sheep and goat numbers following the break up of the Soviet Union, small-scale pastoralists prefer goats as their higher reproductive rate allows the herd numbers to increase more quickly. Does were priced at about US\$60 in Tolaqan market.

In Sardeh and Mohammed Yaqoub the farmers showed no interest in a goat-lending scheme as goats damage the trees in the orchards and need good grazing areas which are no longer found. Closer to Kandahar City there was more interest in restocking with goats because there is demand for fresh milk. The farmers were more interested in a credit scheme to promote lamb fattening provided they were given more time to repay the loan if an animal died. The farmers in Mohammed Yaqoub preferred cows to sheep because they produce more milk and manure and the calves could eventually be sold at a high price. However, a loan scheme to restock with pregnant cows was not attractive because the initial loan of an animal would be very high (US\$600 - 800). Moreover, there would be no income from the sale of a calf for at least two years and all the milk would be consumed by the family. At the end of two or three years there would be substantial interest to repay in addition to the principle.

The farmers interviewed at Shirandam were interested in a credit scheme even though they have had no previous experience of one. The main problem was the risks they would face when taking out a short-term loan. However, one problem with a restocking scheme as compared with 10 years ago was the poor quality of the grazing on the hills close to the village and the limited availability of alfalfa and barley grain. The farmers in Shirandam therefore agreed it was better to have fewer but more productive animals as a result of better management and health care. There was a need to include both sheep and cattle in a scheme in order to spread the risks of disease and a shortage of feed. 


\section{CHAPTER 4. LIVESTOCK MARKETING FROM THE TRADERS' PERSPECTIVE}

\section{Introduction}

This chapter concerns the survey of livestock traders which was undertaken to gain insights about the movement of livestock between farmers, traders and butchers, about traders' behaviour and strategies, and market dynamics in three large livestock markets in eastern Afghanistan. The aim was to ascertain the effectiveness of the marketing chain and to identify any bottlenecks and constraints. The hypothesis was that removing inefficiencies in the livestock marketing chain results in farmers receiving a higher return for their animals thereby increasing their income. It is first necessary to identify any such inefficiencies.

\section{Survey methods}

Sixty traders were interviewed between mid-December 2004 and early January 2005, equally distributed between the livestock markets in Kabul ${ }^{17}$, Kunduz and Kandahar. Including these cities made it possible to contrast the dynamics of livestock marketing in the northern and the southern regions of the country. These dynamics in turn could be contrasted with Kabul, the largest urban centre in Afghanistan with a population of a least three million inhabitants. Due to the public nature of meetings in markets, a fairly short questionnaire was used which took about 20 minutes to apply. It was pre-tested twice at Tia-e-Maskan market in Kabul. The questionnaire used for the survey of market traders is shown in Annex 2. Additional visits were also made to the three markets to conduct informal interviews with traders and a few informal interviews were held with butchers in the three cities.

\section{Market Structures}

On an average day the number of traders operating in the three livestock markets was large (Table 7). Farmers who transported their animals directly to market represented about a third of the number trading. However, considerable variations in the numbers estimated by each trader were apparent which suggests that some of them may have been guessing the answers to question. None of the traders interviewed was a woman. This has implications for issues related to gender equality and

\begin{tabular}{|c|c|}
\hline \multicolumn{2}{|c|}{$\begin{array}{l}\text { Table 7. Number o } \\
\text { traders operating ir } \\
\text { the markets surveyec } \\
\text { on an average day. }\end{array}$} \\
\hline City & Number \\
\hline Kabul & 394 \\
\hline Kandahar & 436 \\
\hline Kunduz & 305 \\
\hline
\end{tabular}
market access. However the results indicate that markets are open to whoever wishes to sell some animals, rather than being dominated by a few large traders.

\footnotetext{
${ }^{17}$ The livestock market within the city boundary (Tia-e-Maskan) was visited rather than the market $30 \mathrm{~km}$ out of town.
} 


\begin{tabular}{|c|c|c|c|c|}
\hline City & Sheep & Goats & Cattle & Buffalo \\
\hline Kabul & $24(11)^{1}$ & $12(9)$ & $8(7)$ & $8(4)$ \\
\hline Kandahar & $22(16)$ & $9(8)$ & $13(5)$ & $0(0)$ \\
\hline Kunduz & $8(12)$ & $6(4)$ & $3(8)$ & $0(0)$ \\
\hline
\end{tabular}

The number of animals marketed by each trader on a typical day in December 2004 was small although the same trader was sometimes selling two different types of livestock (Table 8). Similar numbers of sheep, goats and cattle were being traded in Kabul and Kandahar whereas in Kunduz the numbers were lower, on average. Trading in buffaloes was only found in Kabul since there continues to be a shortage of cattle from Afghan sources to meet the demands of the population that has expanded quickly over the last few years. About half as many goats as sheep were being marketed in Kabul and Kandahar but similar numbers of goats and sheep were being marketed daily in Kunduz.



Plate 1. A crossbred bull belonging to a local farmer selling for $\$ 1,080$ in Kabul market before the Eid-al-Adha in January 2005. (Photo E. Thomson)

Different categories of traders operated in the markets, as is the case in markets for other farm products. There were traders that purchased animals from farmers in the villages and towns and sold them in the local town market. Other traders purchased animals in a town or city market and transported them to another market, sometimes covering several hundred kilometres. There they sold them to butchers. Then there were intermediaries based in the main markets who bought from traders or farmers coming to the market and sold the animals within

hours to other intermediaries or to butchers. Kuchis operated in this way in Kandahar market as a strategy to generate income, albeit earning a small profit on each animal traded. Agents also operate in markets that facilitate transactions between sellers and buyers for a small fee. Thus, a variety of practices, marketing channels and incentive structures are found among the different actors buying and selling livestock. Unravelling the full complexities of this aspect of livestock marketing was beyond the scope of the project but it is a subject that deserves attention. 


\section{Prices of different livestock according to species and size}

Traders were asked the prices of cattle, sheep, goats and buffaloes of different sizes in order to gain an insight into the additional income that a farmer might earn if he kept his animals for a longer time. Although factors such as breed, finish of the animal and live weight undoubtedly affect prices, sheep increase in value far more than goats as they increased in size, whereas the progression in price from small to large cattle was smaller $(\text { Table } 10)^{18}$. The results suggest that the increase in income generated from sheep is greater than from goats although selling a sheep for over US $\$ 200$ would require keeping and feeding it for three or four years. Buffalo were only seen in Kabul market where the price for small, medium and large animals was US $\$ 361$, US $\$ 653$ and US $\$ 986$, respectively. The higher prices of animals in Kandahar compared to Kabul market is difficult to explain. The data in Figure 1 show that the price of one-year-old rams is consistently higher in Kabul than in Kandahar.

\begin{tabular}{|c|c|c|c|c|c|c|c|c|c|}
\hline \multicolumn{10}{|c|}{$\begin{array}{l}\text { Table 10. Prices (US\$) of small, medium } \\
\text { Kabul, Kandahar and Kunduz markets. } \\
\text { Sheep }\end{array}$} \\
\hline & Small & Medium & Large & Small & Medium & Large & Small & Medium & Large \\
\hline Kabul & 53 & 96 & 216 & 34 & 47 & 58 & 253 & 460 & 734 \\
\hline Kandahar & 64 & 123 & 273 & -1 & -1 & -1 & 459 & 993 & 1781 \\
\hline Kunduz & 53 & 91 & 180 & 31 & 38 & 73 & 148 & 255 & 410 \\
\hline
\end{tabular}

The size and finish of an animal were the two main criteria that traders used to decide on the price of an animal. A study by Rodriguez et al. (1995) in the livestock market in Quetta in Balochistan Province of Pakistan showed that live weight and seasonality were the two main factors determining price, However, rainfall in the current and previous month was positively related to the prices that producers expected to receive for their livestock. The traders in the three markets studied in Afghanistan also take the sex of the animal into account. Butchers estimate the amount of meat that an animal will produce to decide the wholesale price that they offer.

\footnotetext{
18 The prices in Table 10 may be compared with those for mid-2002 in Kabul (Thomson et al., 2003, Table 21).
} 


\section{Credit and finance}

None of the traders was using the formal sector to obtain credit (Table 11). A weak banking sector and the high transaction costs of short-term credits are two possible explanations for this finding. They did have access to modest amounts of credit through informal channels.

The maximum amount that they had access to generally exceeded the value of the average number of animals that they might sell on an average day (Table 8). For example, using an average price of US $\$ 100$ for a sheep, the maximum amount of credit accessible would be equivalent to selling 18 to 35 sheep in a day. Traders therefore had access to sufficient working capital to operate their enterprise.

Providing the transaction costs were not too high, there may be a role for the financial services of the formal sector to facilitate the trading of livestock and livestock products. However, because traders were already making quite extensive use of credit from the informal sector, the formal sector would have to offer a more appealing product than the one that is currently available. Further studies are needed to evaluate the manner and frequency with which traders use credit and whether better provision of financial services would be useful to operate their business.

\section{Estimate of marketing margins}

Quantifying the difference between the farm-level price and the retail price paid by consumers for a product and the components that contribute to this difference is important when assessing the efficiency of a marketing chain. If the difference is large because some of the marketing charges are excessive, reducing these charges could result in the farmer receiving a higher return and/or the price to the consumer being reduced. Therefore, one of the major objectives of the present study was to evaluate the slope of the marketing cost function (see Box 2) and to identify potential opportunities by which the slope of this function could be reduced, thus lowering the price paid by consumers and increasing prices paid to farmers for different livestock products. 


\section{Box 2. The efficiency of the marketing chain - some conceptual issues.}

The difference between the price paid for a product by a consumer (the retail price) and the price paid to a farmer is composed of marketing expenses. The figure below provides a conceptual diagram of how to consider efficiencies in the marketing sector. If marketing expenses (see list in text) are high, the cost function for marketing is relatively steep, and the difference between the price paid by the consumer (price $\mathrm{C}_{0}$ ) and the price paid to the farmer (price $P_{0}$ ) is large. If efficiencies in the marketing chain are achieved, the slope of the marketing cost function becomes lower, or 'flatter' and this could result in a lower price paid by consumers (price $C_{1}$ ) and/or a higher price received by farmers (price $P_{1}$ ). Other scenarios are also possible, such as a lower consumer price, without the price paid to the farmer changing.

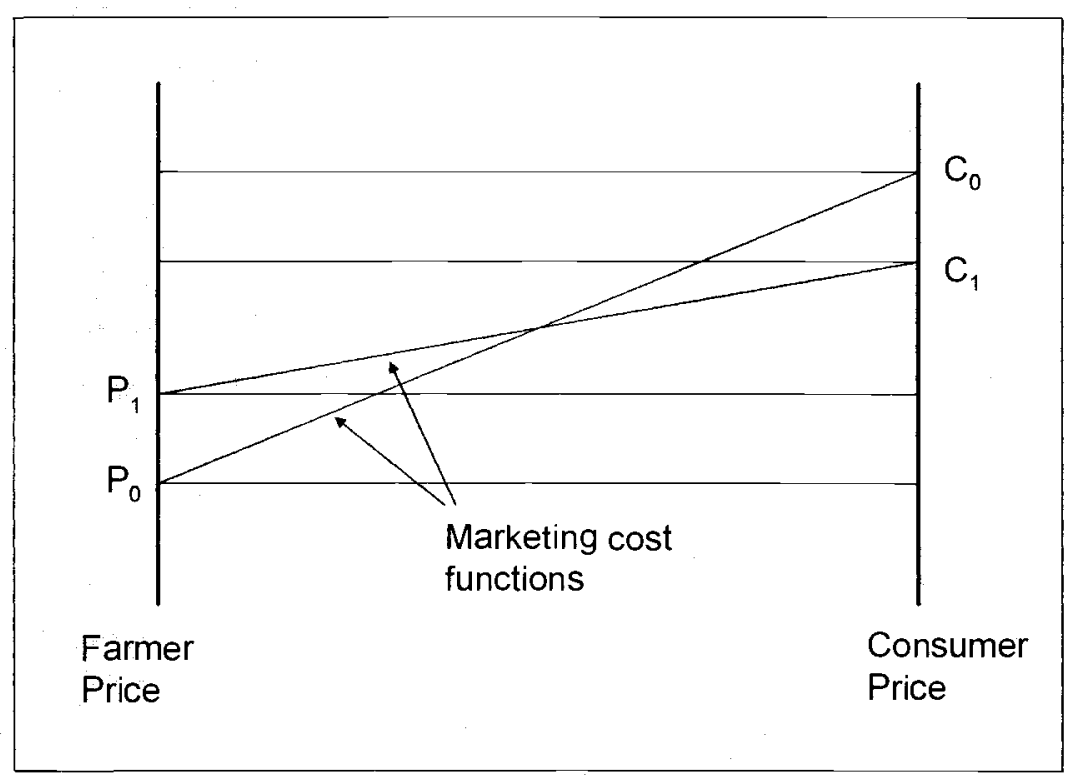

The main expenses that traders face when moving livestock between markets are transport, market fees, night accommodation and informal charges. In addition, customs charges and tariffs are levied on livestock which cross international borders. Transport charges are kept at reasonable levels since there is competition between transporters for clients or between the many traders that own a truck. Night accommodation charges are levied in Kabul market since animals that are not sold on one day have to be fed and watered. Such accommodation is not needed for livestock marketed in Kandahar and Kunduz markets since unsold animals are taken away at the end of the day. 


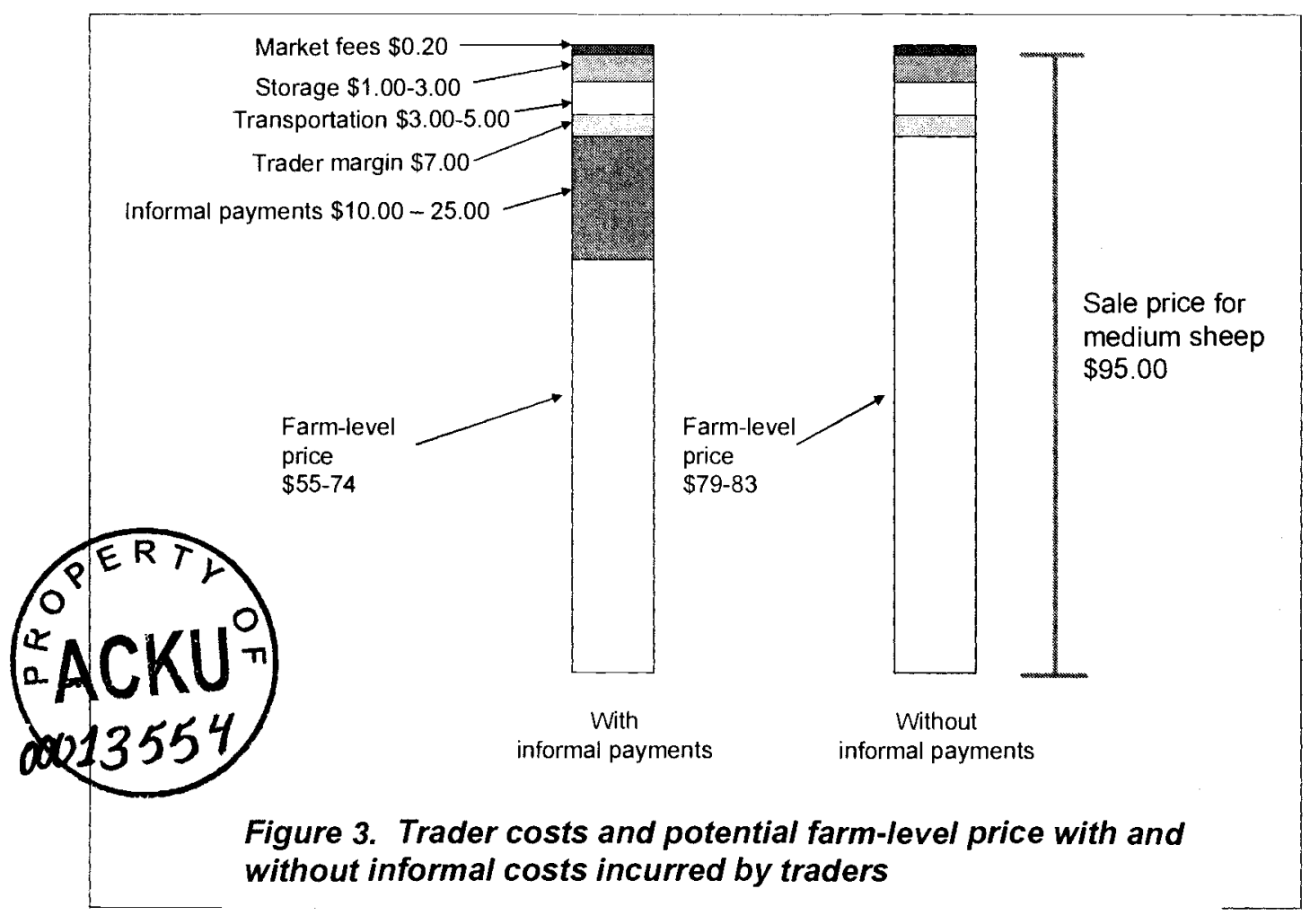

Another expense is the fee levied by the municipality when animals enter the market. Even though the fee is fixed by the municipality, overcharging is common. Some traders even complained that they were charged to take unsold animals out of the market. Typical costs incurred by traders are shown in Figure 3. The trader margin is $7.6 \%$ of the wholesale price in the example in Figure 3. The largest charges facing traders and transporters are the informal charges that they have to pay along the routes that they travel which can account for US\$10-25 for a sheep sold for about US\$95. The potential impact that this could have on farm-level prices, assuming that the sale price remains the same is also shown in Figure 3.

Apart from the informal payments, there appears to be little scope to increase farm prices by reducing marketing costs, assuming that traders pass any savings made back to the farmer which is far from certain. For example, cutting transportation costs by half would only raise the farm-level price by $3 \%$ and reducing transport costs by this amount is unlikely. In the example in Figure 3, however the farmer receives only about $58-78 \%$ of the wholesale price when informal charges are levied. This could potentially increase to $83-88 \%$ if these informal charges were removed.

The high level of informal payments that traders and transporters face at the frequent checkpoints may be a cause for concern. Indeed, traders and transporters of all farm products face the same problem. Efforts were made during visits to markets to untangle 
this complex subject but the information provided by traders was often suspect and confusing. Some said there were few checkpoints whilst others complained that they were stopped many times. These different opinions are partly related to an unwillingness to discuss this sensitive subject, and differences in the distance travelled, the route used and the region of the countiy where the journey is made. The smuggling of animals into the country was not discussed, although several traders mentioned that cattle and buffaloes are imported from Pakistan along remote roads through the mountains. This has serious implications for the transmission of diseases across international borders.

In essence there are official check points manned by customs officers at the edge of the main cities and international borders, and traffic police check vehicle papers at provincial borders and elsewhere. Customs duties are only charged on products being exported. Less clear is the information gathered about the numerous unofficial checkpoints which traders often complained about. They are manned by an assortment of police, soldiers, local militia and other unknown individuals. In all cases traders and transporters have no option but to comply with the demands for payment and often pay a bribe on top as well. In the case of live animal marketing, the informal payments could range between US $\$ 10$ and US $\$ 25$ (Figure 3). They represent nearly 10 to $25 \%$ of the wholesale value of the animal and significantly affect the efficiency of the marketing chain. Since they represent a significant cost to the traders there is little doubt that they are affecting the market. Their removal would increase the producer price and/or reduce the consumer price. Given the number of traders operating in the markets in the cities the market is probably fairly competitive at the consumer end and so a reduction on informal payments is highly likely to result in an increase in the producer price as well as a reduction in the consumer price. The current high consumer price makes red meat less competitive with imported frozen chicken, for example.

While informal payments appear to be a significant problem, it will take some time before central government has the authority across the whole country to resolve the problem ${ }^{19}$. This is a reflection of the prevailing macro-economic, security and political environment currently found in Afghanistan. Indeed, problems related to costs and risks of transporting goods around different parts of the country are not only confined to the livestock sub-sector. For many other sub-sectors and products, there are also frequent reports of problems of this sort (e.g. in the wheat sub-sector, Mercy Corps Afghanistan, 2004). As such, this problem needs to be addressed by the Ministry of Transportation, the Interior Ministry and the law enforcement agencies in general. What is clear from this preliminary analysis is that reducing informal payments could improve farm-level

\footnotetext{
${ }^{19}$ The degree of security varies between provinces. Transporters stated that security along the main roads between the north and Kabul over the Salang Pass and on to the border with Pakistan at Torkham, was far better than between Herat and Kandahar, for example.
} 
prices more than any other intervention or course of action presently available along the marketing chain.

\section{Physical Infrastructure}

The three markets operate in open spaces which have no concrete paving or paved access roads, drainage is poor to non-existent and access to uncontaminated water for the animals is limited. Tia-e-Maskan Naqaash livestock market in Kabul stands on commercially valuable land which is increasingly surrounded by new buildings destined for use as business premises. The four partners operating the two livestock markets in Kabul pay an annual lease of US $\$ 310,000$ to Kabul Municipality ${ }^{20}$.

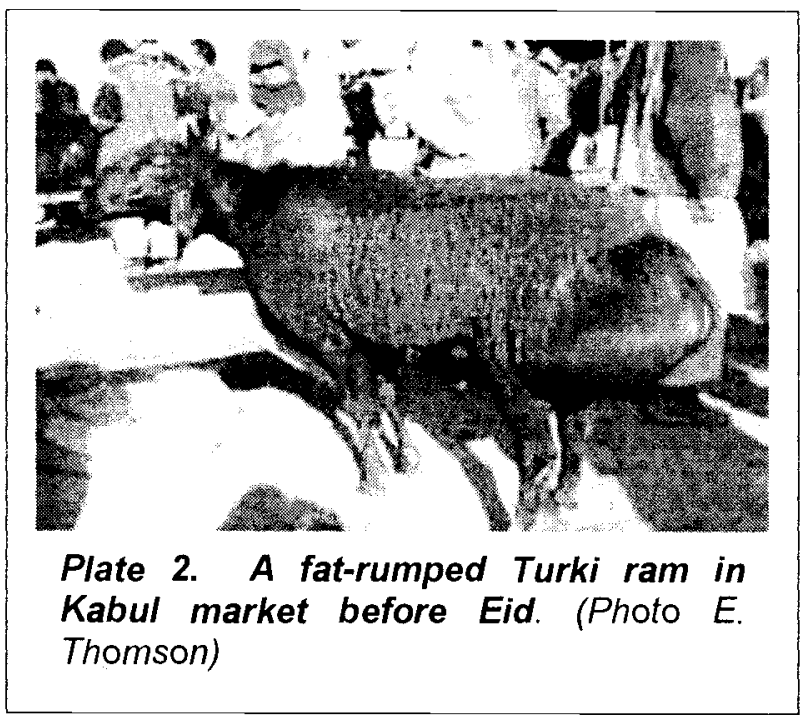
It has primitive barns on three sides where traders house animals overnight. In Kunduz the livestock market is located within the city, with business premises on one side and private houses on the other sides. The livestock market in Kandahar is at the edge of the city and has private houses and business premises close by. The hygiene at all three markets is atrocious and after heavy rain stagnant water from ponds is said to contaminate the water in local wells. These conditions undoubtedly affect the health and welfare of the animals, not to mention that of the local residents, farmers, traders and butchers, and put the health of meat consumers at risk. Indeed, traders frequently complained about the poor infrastructure when asked about the problems they face when operating their businesses. Substantial investment is needed to improve the physical infrastructure of the livestock markets, particularly as the traders already pay a fee to the municipality for each animal that they bring to the market to sell. If the quality of the infrastructure were improved, the traders would no doubt be willing to pay a small additional fee to offset the cost of the improvements.

\footnotetext{
${ }^{20}$ The other market is referred to as the Company Naqaash market and it will no doubt become more important as pressure to use the site for commercial purposes at Tia-e-Maskan increases. The Company Naqaash market was not visited by the researchers.
} 


\section{Retail selling of meat}

Informal interviews with four butchers in Kabul found that each one typically slaughtered 100 sheep, 28 goats and 28 cattle in a month. The four butchers interviewed in Kandahar each slaughtered in a typical munth 40 sheep, seven goats and one head of cattle. Although goats accounted for about a fifth of the small ruminants being slaughtered by this small sample of butchers, the butchers were unanimous that consumers preferred mutton to goat meat. This resulted in the price of goat meat being marginally (4\%) cheaper than mutton in Kabul but $15 \%$ cheaper in Kandahar. A number of reasons were given for this preference, such as mutton having more flavour, it cooks faster probably because it is more tender and goat meat is too lean and bony. Beef and buffalo meat had a similar price (Table 9). The local preference for fat can be seen from its high price. Imported frozen chicken legs were the cheapest meat, priced at about US\$1.50 per kg. Notices showing the official prices of mutton, goat meat and beef which are announced by the government are posted in some butchers shops but the actual prices paid by consumers are higher

Table 9. Prices of red meat in butchers shops in Kabul in February 2005. (US\$/kg)

Mutton with bone ${ }^{1}$ 3.7

Calf meat with bone 3.1

Beef/buffalo with bone 2.5

Beef/buffalo without bone $\quad 2.9$ Fat from tail of sheep

3.6

${ }^{7}$ In mid-2002 the retail price of mutton with bone in Kabul was about US $\$ 2.50$ per kg (Thomson et al., 2003).

than the official price. 


\section{CHAPTER 5. MARKETING OF NON-EDIBLE LIVESTOCK PRODUCTS}

\section{Introduction}

The project included an initial examination of the marketing of skins, hides and wool as these are the main non-edible livestock products being traded in the area where the project took place. Interviews with farmers and other key informants showed that combing of goats for their down is seldom practised and keeping of Karakul sheep for the pelts of the lambs is uncommon in the study areas. However, the collection, processing and export of goat down and Karakul pelts is continuing in other areas of Afghanistan. In the west, goat down is collected and exported (Altai Consulting, 2005). Indeed, in the past, several hundred tonnes were available for export each year (see Table 2). The keeping of Karakul sheep continues to the west of the study area but numbers are much lower than 25 years ago (CSO, 1978) ${ }^{21}$. At that time Afghanistan was said to be the world's third largest producer with some two million pelts being exported annually (Demirüren, 1975, page 6). However, this is a higher number than shown in Table 2. A study of the Karakul sheep sector in Afghanistan is urgently needed as it will undoubtedly recover during the coming years.

\section{Skins and Hides}

One or two traders in each of the three cities included in the study were interviewed to gather preliminary information about the marketing chains for fresh skins and hides in the eastern half of Afghanistan. Butchers in villages and towns deliver fresh skins and hides to intermediaries or traders. Intestines are included with the skins of sheep and goats $^{22}$. The intermediaries either sell the skins and hides to other traders who arrange onward transport to the main collection centres such as Kunduz, Kabul and Kandahar, or sell directly to these centres. For example, Kunduz city is the collection point for skins, hides and intestines from different places in Kunduz, Baghlan, Takkar and Badakhstan Provinces in north-east Afghanistan. When the traders in Kunduz have gathered sufficient numbers, they load the skins and hides on trucks which leave for Kabul. Alternatively, trucks travel directly from Kunduz to the tanneries in Pakistan, crossing the Afghan-Pakistani border at Torkham. Intermediaries in Kabul collect skins, hides and intestines from butchers and sell them to large traders. They in turn sell them to Pakistani buyers who transport the skins and hides to tanneries in Pakistan. The traders

${ }^{21}$ Data cited by Kerven, Russel and Laker (2002) shows that in the late 1990s more pelts $(82,000)$ supposedly from Afghanistan were auctioned at the Danish Fur Centre than from Namibia (about 66,000 ). The true origin of the majority of the Afghan pelts, however, needs to be confirmed.

22 The intestines are cleaned and treated with a preservative then exported to Dubai, Lebanon and, in the past, Germany for use as the casings for sausages. However, for the last few years countries of the European Union no longer import intestines due to the risk of spreading disease. 
in Kandahar arrange transport of skins and hides by truck to the Afghan-Pakistani border at Spin Boldak / Chaman and on to Quetta in Pakistan. A study by Mahmood and Rodriguez (1993) reported on the processing of skins in Quetta. From there they are transported to tanneries, many of which are located near Karachi.

The skins and hides collected by the main traders in Kunduz, Kabul and Kandahar are sorted, salted and stacked in piles prior to being transported. In Kunduz there is a shortage of covered storage space in rooms surrounding the open yard (sarai) used for trading. This results in the fresh skins and hides being stored in the open under filthy conditions, particularly in the wet winter season. Whereas the low temperatures in winter are better for storage, the high temperatures in summer result in damage to the skins and hides and therefore loss of quality, even though they have been salted. In summer in Kunduz the skins and hides are spread out in the open to dry for about 25 days. This in turn requires considerable space which is limiting. It is not known whether skins and hides are sun-dried in Kabul and Kandahar. The owner of the sarai in Kunduz charges traders 1 Afs (US\$0.02) for each skin traded but none of the income is used to improve the conditions in the market.

Raw skins and hides are nearly all exported to Pakistan for tanning because the small family-owned tanneries that used to operate in Afghanistan were either destroyed by the fighting spread over 20 years or they were unable to compete with the more efficient modern plants in Pakistan. About 20-25 years ago there used to be 30 family-owned tanneries near Tashkurgon, a town between Kunduz and Mazar-e-Sharif, but only 10 operate today.

Because of the large number of traders operating in the three cities visited, it was not possible to estimate the flows of skins and hides with any precision. In the sarai visited in Kunduz the 100 or so traders visited each handled widely differing quantities of skins. In Kabul one trader said there were 100 skin and hide traders operating 25 years ago but only 30 today. One trader interviewed in Kunduz estimated the daily flow was 5,000 skins and hides which appears to be a high number given the population of livestock in north-east Afghanistan. He himself was dispatching about one truckload a month, each loaded with 8,000 - 10,000 skins but some of the large traders sent more loads. Just after Eid-al-Adha in January 2005 seven trucks left for Kabul loaded with skins and hides. However, traders agreed that in general the numbers of skins and hides being traded had decreased during the recent drought but numbers were now recovering. Indicative prices of skins, hides and intestines are shown in Table 12. Sales margins are not presented as the traders provided values that were quite variable. 
Table 12. Prices (US\$) paid by traders in Kunduz and Kabul to butchers and intermediaries delivering fresh skin and hides, and typical transport costs and customs charges.

\begin{tabular}{lcccc}
\hline & Cattle hide & Sheep skin & Goat skin & Buffalo hide \\
\hline Purchase price & $10.4-12.5^{1}$ & $5.4-5.9^{2}$ & $2.5-2.9^{2}$ & 26.8 \\
Transport costs $^{3}$ & 0.89 & 0.36 & 0.27 & - \\
Customs duty $^{4}$ & 0.66 & 0.25 & 0.16 & - \\
\hline
\end{tabular}

${ }_{1}^{1}$ Quoted as 30 Pakistani Rupees (US\$0.54) per foot $(30.5 \mathrm{~cm})$ in Kabul market.

${ }^{2}$ Includes intestines. ${ }^{3}$ From Kunduz to Karachi. ${ }^{4}$ Applies to all skins and hides being exported to Pakistan. The duty is paid at the customs house (gumruk) in Kabul. Once paid, it allows the trucks to pass checkpoints between Kabul and Torhkam on the Afghan/Pakistan border and to cross into Pakistan. It is probable that further customs charges are made on the Pakistani side of the border.

\section{Wool}

Single visits were made to the government-owned woollen mill in Kabul and to the two government-owned woollen mills in Kandahar, one of which no longer operates. A group interview was held with wool traders in Kabul and four traders were interviewed in a group in Kandahar. The findings from these two interviews are presented in this section. Prices of wool, woollen yarn and goat hair yarn quoted by traders are shown in Annex 3 and information collected at visits to one woollen mill in Kabul and one in Kandahar is shown in Annex 4.

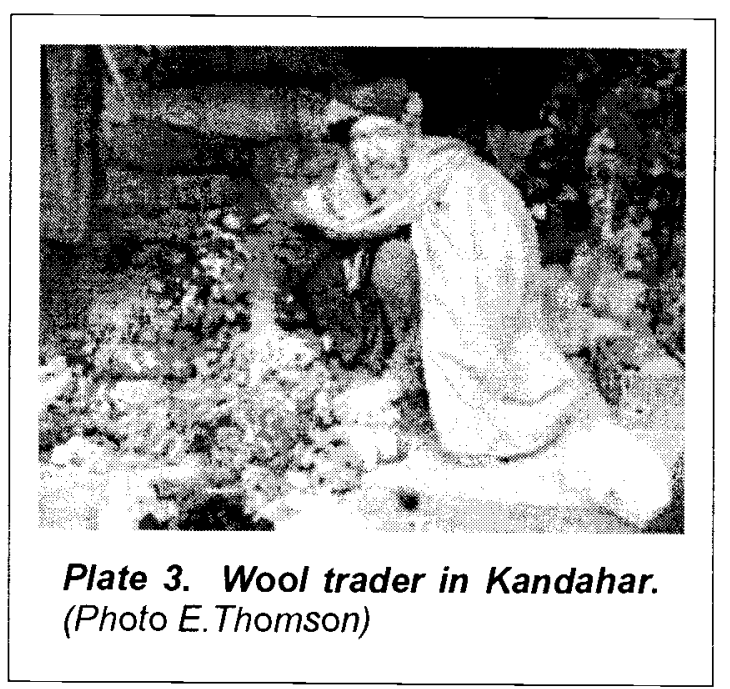

Wool is the basic raw material for the domestic carpet and rug industry. Annual production peaked at about 33,000 tonnes in the mid-1990s, but today it is estimated to be well below that amount due to the large losses of sheep during the recent severe drought (Table 2). These estimates of wool production exclude an unknown amount that is used directly by rural families for filling cushions and for spinning into yarn for carpets, socks, etc. Indeed, in eight of the nine villages visited (see Chapter 3) wool was not 
being sold outside the village as the quantities clipped from the small numbers of sheep were very small ${ }^{23}$.

The group of wool traders visited in Kabul was located in the Said Qenahat Market in the Baghi Ali Mardan area. Between 100 and 110 traders use a cluster of steel containers as their business premises but it is not known how many other traders there are elsewhere in the city. Whereas in the past most of the wool came from Afghanistan, today uncleaned and washed wool is being imported from Iran, Iraq and Turkmenistan, as well as from Afghanistan ${ }^{24}$. One trader who had been in business for 36 years said that during the time of King Zahir Khan in the 1960s and early 1970s and President Daoud Khan in the 1970s wool was exported to Russia. His highest annual volume of woollen yarn sales in the past was 30 tonnes. At that time traders and sheep owners, who were often Kuchi because they owned large herds, came to the wool market between June and November to sell uncleaned wool. Today his annual sales of woollen yarn were about 5 tonnes, as supplies of wool were limited. Another trader in the group sold about 24 tonnes woollen yarn annually ${ }^{25}$. It was sold to buyers from the northern provinces such as Balkh, Jowzjan, Kunduz and Baghlan, and from the western area of Kabul. They sell the yarn which is dyed and use the fine yarn for the knots in carpets and the coarse and stronger yarn for the warp and weft. The traders complained about the lack of a large wool washing facility in Kabul.

Several thousand women were reported to be employed to wash, sort and spin wool into yarn but the number could be higher. For example, women living in Kabul collect the cleaned wool from the trader and then card and spin the wool into yarn at home using the traditional hand-held spindle. On returning the yarn to the trader they are paid 0.50 $0.85 \mathrm{US} \$ \mathrm{~kg}$ yarn. In summer it takes about a day to spin $1 \mathrm{~kg}$ of yarn but in winter only half this amount is spun in a day because of the cold working conditions. Women generally spin for an hour or two each day in-between their various other tasks. Thus, they might spin 3-4 kg in one month in winter when they are slightly less occupied for which they could earn US\$2-4. It is not known whether they keep the earnings. In another arrangement, men from villages as far away as Bamyan Province collect the cleaned wool from the traders and distribute it among women in their villages. One man said he organised 700 women to spin wool into yarn in a cluster of villages in the

\footnotetext{
${ }^{23}$ The Turki sheep breed kept by families in Baloch village in Kunduz Province is not clipped because of the extremely coarse wool that it produces.

${ }^{24}$ There are many reports that Merino wool is imported through Pakistan and some of this comes from Belgium. The origin of the wool is unknown but some of it probably comes from New Zealand and Australia. The fineness and lustre of the pile of many new knotted carpets seen in Kabul suggests that Merino wool is being used quite often.

${ }^{25}$ The average annual sales of yarn were about 10 tonnes for the five traders interviewed. Thus, if there were 100 traders operating in the cluster, the total production would be about 1,000 tonnes annually of yarn of different colours and qualities. This is equivalent to about 2,000 tonnes of raw wool, or the clip from one million sheep out of the total population of 8.77 million sheep in 2003.
} 
Panjsher Valley. The men pay the women for the work done and return the woollen yarn to the traders in Kabul.

The wool traders complained that buyers would often came from Pakistan to purchase carpets made in Afghanistan at reduced prices and then export them to Europe and the USA. The buyers thereby made good margins at the expense of the Afghan sellers. It was also reported that Afghan carpets made in Pakistan were being sold as carpets made in Afghanistan ${ }^{26}$.

There are about 20 wool traders operating in Kandahar who purchase mainly uncleaned wool directly from Kuchi and farmers located in the south-east of Afghanistan. The three wool traders interviewed individually purchased $6.8,22.5$ and 3.6 tonnes uncleaned wool in 2004. The traders contract Kuchi women in the refugee camps and living in the city to wash, sort and comb the wool and spin it into yarn. They earn US $\$ 0.63 / \mathrm{kg}$ yarn delivered which is within the range paid in Kabul. The three traders were selling widely varying amounts of woollen yarn, from 68 to $1,000 \mathrm{~kg}$ annually. One trader was selling annually $18 \mathrm{~kg}$ and another $50 \mathrm{~kg}$ of the yarn made from goat hair. It is woven elsewhere into fabric and rope that the Kuchi use for their tents.

\footnotetext{
${ }^{26}$ Knotted carpets are made in Peshawar by Afghans who settled there after fleeing their country because of the wars in the 1980 s and 1990s. The size of this industry is unknown but it appears to be well organised and linked to international traders. This adds to the competition faced by traders in Afghanistan. Anecdotal reports suggest that carpets made in Pakistan use a considerable amount of wool of non-Afghan origin. In this case they should not be sold as genuine Afghan carpets, but many undoubtedly are. It is known that Merino wool is imported into Pakistan, some of it through Belgium, and some of it finds its way into Afghanistan. As the number of Afghan refugee camps in Pakistan gradually decreases, the volume of carpets made in the camps may decrease. However, it is not clear whether this will actually reduce the number of so-called Afghan carpets that are made in Pakistan.
} 
This chapter forecasts the future demand for mutton in Afghanistan until 2010. To make the forecasts the current and projected per capita GDP and per capita growth in GDP in Afghanistan are used as they are significant factors affecting the demand for meat (Schroeder et al., 1995; Delgardo et al., 1999). As with most forecasts, however, their usefulness depends on many factors including the parameter values and the assumptions in the model. Moreover, a forecast indicates one outcome in a situation where markets are prone to shocks, consumer preferences can change, and policy interventions can create conditions not
Table 13. Annual per capita GDP and sheep and goat meat consumption in Afghanistan and selected countries in the region. (Source: FAOSTAT)

\begin{tabular}{lcc}
\hline & $\begin{array}{c}\text { Per } \\
\text { capita } \\
\text { GDP } \\
\text { (US\$) }\end{array}$ & $\begin{array}{c}\text { Sheep/goat } \\
\text { meat con- } \\
\text { sumption } \\
\text { (kg/capita) }\end{array}$ \\
\hline Afghanistan' $^{1}$ & 190 & 1.9 \\
Tajikistan & 205 & 2.3 \\
Uzbekistan & 420 & 3.2 \\
Pakistan & 470 & 3.5 \\
Iran & 2,070 & 6.6 \\
Turkey & 2,790 & 4.7 \\
\hline 'Data from NRVA (2003). & \\
\hline
\end{tabular}
anticipated in the forecast. The forecast presented below should therefore be used with caution and whenever possible updated using more precise information when it is available.

Afghanistan has the lowest per capita GDP and the lowest mutton and goat meat consumption in the region (Table 13). At these low levels of per capita GDP demand for meat is generally elastic in relation to increases in income, and in some instances it is highly elastic. For example, in their study Schroeder et al. (1995) included data from 35 developing and developed countries over the years 1970-85. They found that a $1 \%$ increase in per capita income resulted in a $2 \%$ increase in the demand for beef and poultry and a $3 \%$ increase in the demand for mutton. In another study Delgardo et al.

Table 14. Income elasticities of demand for pork, mutton and beef for different groups of developing countries. (Source: Delgardo et al., 1999).

\begin{tabular}{lccc} 
& $\begin{array}{c}\text { Poorest } \\
\text { third }\end{array}$ & $\begin{array}{c}\text { All } \\
\text { coun- } \\
\text { tries } \\
(\mathbf{n}=\mathbf{6 4})\end{array}$ & $\begin{array}{c}\text { Richest } \\
\text { third }\end{array}$ \\
\hline $\begin{array}{l}\text { Pork and } \\
\text { mutton }\end{array}$ & 0.96 & 1.10 & 1.30 \\
Beef & 0.72 & 0.65 & 0.57 \\
\hline
\end{tabular}

(1999) reported the income elasticities of demand for three meats in 64 developing countries (Table 14). In Afghanistan an income elasticity of demand of 2.8 was estimated for mutton using NRVA data (NRVA, 2003). This is a value similar to the one reported by Schroeder et al. (1995). However, the NRVA data was not specifically collected to evaluate demand elasticities and consumer behaviour with regard to changes in income. For this reason 
the more conservative income elasticities presented in the Delgardo et al. (1999) report are used to make a forecast of the future demand for mutton and goat meat.

Growth of per capita GDP is the second factor that affects the demand for meat. In Afghanistan it has been well over $10 \%$ for the last few years (World Bank, 2005), which is a high value given the present circumstances in the country. Indeed, estimated growth in GDP was $23 \%$ in 2002 and $16 \%$ in 2003. In the absence of a substantial deterioration in the overall macro-economic, political and security situation, relatively high rates of GDP growth are expected to continue until 2010, if not for longer (Government of Afghanistan, 2004).

Using the information presented above and an estimated value of the sheep market in 2005 , forecasts of the value of the sheep market in 2010 were made (Table 15). Even at the more conservative income elasticity, there was about a $50 \%$ increase in the value of the sheep meat market in five years. Thus, there are good prospects for a substantial increase in the demand for red meat over the coming five years. However, will the domestic market be able to meet this demand? At the moment national livestock numbers are substantially down from 10 years ago (Table 2) as a result of deaths and distress sales of animals associated with the unprecedented drought during the last few years. Indeed, livestock numbers have in many areas of the country been reduced by 70 to $85 \%$.

\begin{tabular}{|c|c|c|}
\hline & $\begin{array}{l}\text { Inc } \\
\text { elas }\end{array}$ & $\begin{array}{l}\text { ne } \\
\text { ity }\end{array}$ \\
\hline & 0.9 & 1.3 \\
\hline $\begin{array}{l}\text { Current value of } \\
\text { mutton market } \\
\text { (million US\$) }\end{array}$ & & \\
\hline $\begin{array}{l}\text { Net annual growth } \\
\text { rate in the demand } \\
\text { for mutton (\%) }\end{array}$ & 9 & 13 \\
\hline $\begin{array}{l}\text { Increase in demand } \\
\text { compounded over } 5 \\
\text { years }(\%)\end{array}$ & 53 & 84 \\
\hline $\begin{array}{l}\text { Value of demand } \\
\text { compounded over } 5 \\
\text { years (million US\$) }\end{array}$ & 207 & 248 \\
\hline $\begin{array}{l}\text { Estimated assuming } 8.7 \\
\text { an offtake of } 20 \% \text { and fa } \\
\$ 77 \text { per sheep. }\end{array}$ & & of \\
\hline
\end{tabular}

Table 15. Forecast of the value of the sheep market by 2010, assuming a $10 \%$ annual growth in GDP. elasticity

Current value of market

Net annual growth rate in the demand for mutton (\%) Increase in demand compounded over 5 years $(\%)$

Value of demand compounded over years (million US\$) an $\$ 77$ per sheep.

One study estimates that the annual recovery rate for small ruminant numbers could be between 8 and 12\% (Thomson et al., 2003). Thus, the growth rates for demand for mutton and goat meat demonstrated above could be more or less matched by the anticipated growth in the supply. Provided the political and economic conditions continue to improve and prices of mutton and goat meat remain favourable, the future prospects for the sheep sector, and by analogy the goat sector, in Afghanistan is good. 


\section{CHAPTER 7. INCREASING RETURNS TO LIVESTOCK OWNERS}

\section{Introduction}

The aim of the study was to 'identify market opportunities for livestock and livestock products and constraints to producers receiving higher returns from livestock products', as a viable alternative to poppy production. This Chapter firstly discusses the adding of value to skins, hides and wool and presents some solutions to the constraints that prevent producers receiving higher returns. It then considers whether increasing the efficiency of red meat marketing chains would benefit the meat consumer, the farmer or both. Finally, a number of interventions are examined which could enhance the incomes of livestock owners. The remarks take into account the purpose of the RALF programme which is to 'develop and promote innovative alternative livelihood options for rural Afghans currently economically dependent on opium poppy'.

\section{Marketing opportunities for skins, hides and wool}

The revenue from the sale of fresh skins and hides accounts for less than $5 \%$ of the total market value of live animals sold. Therefore, if prices of these products increased because informal payments were removed and the increase was passed back to the farmer, he would perceive only a small change in the farm-level price. Therefore, establishing an Afghan tanning and leather industry may be of more benefit to the national economy rather than to the livelihoods of farmers, as it would generate employment and economic wealth in the processing sector. Such a domestic industry would indeed capture the value-added potential of fresh skins and hides which is presently lost to Pakistan. However, it is unclear whether it could compete with the modern tanneries in Pakistan and cheap imported leather goods. Feasibility studies are needed to examine the rationale for investing in new Afghan tanneries and reestablishing businesses that produce leather goods before attempting to attract the necessary capital to invest in such plants. It is possible that Afghan leather goods would have difficulty competing with imported leather goods from China unless there was a good demand for more expensive Afghan products.

Wool is also just a small part of the total income from sheep ownership. Indeed, if five ewes and one replacement ewe produced $12 \mathrm{~kg}$ wool annually worth US $\$ 10$, this contrasts with the US $\$ 300$ income from the sale of four lambs at six months of age and one cull ewe. Unlike skins and hides, however, rural families add value to wool by using it to fill cushions and mattresses and for carpets and socks. The knotted carpets made by women in the remote villages supply a niche market in the West. In the late 1970s handicrafts in Afghanistan consisting mainly of woollen carpets and rugs, were valued at US $\$ 20$ million and carpets and rugs accounted for $9 \%$ of exports (Khan and lqbal, 1999). 
In order for the women in the villages to gain a higher return, new quality assurance schemes are needed that could guarantee that Afghan carpets are genuinely made in the country and use wool that was produced, spun and dyed in the villages. Private sector initiatives are needed that estabiish such schemes, supported by suitable government policies. This demand-driven approach would help genuine Afghan carpets compete on the international market with Afghan carpets that are made in Pakistan, sometimes using non-Afghan wool.

\section{Schemes to increase the incomes of farmers from livestock}

The main constraints to increasing income from livestock at the farm level in this study were a complete absence of livestock or insufficient numbers to generate a marketable surplus, and an inability to exploit existing market opportunities. New schemes to provide the poorest families with livestock and to enable new and existing livestock owners to increase their animal numbers and to add value to their animals by, for example, feeding them to heavier weights need to be implemented. These schemes would help to both reduce poverty levels and generate income which could help farmers to stop growing poppies.

\section{Restocking schemes}

Thomson et al. (2003) have pointed out that animal numbers will in any case gradually recover over time provided rainfall levels return to previous patterns. For example, small ruminant and cattle numbers were estimated to take 6 to 8 and about 10 years, respectively, to recover to pre-drought levels. However, compared with 10 years ago a higher percentage of rural families own no livestock (FAO, 2003). It is estimated that over 91,000 families $^{27}$ lost all their livestock during the drought. These families are often the poorest and have no way of acquiring the animals to re-start livestock keeping. Without some form of assistance with restocking they are unlikely to become livestock keepers again.

Restocking schemes of various configurations have been applied in Afghanistan since the mid-1980s, if not before. The huge decrease in livestock numbers in the past decade suggests that there is an urgent need to consider restocking schemes again. In general, restocking schemes need to be carefully planned and implemented to ensure that they reach the desired outcomes. For example a scheme to assist families with no livestock to start livestock keeping again may need to be different to one where the aim is to increase the size of existing herds/flocks. A comprehensive review of re-stocking schemes is beyond the scope of this study, but a review of the strengths and weakness

\footnotetext{
${ }^{27}$ Based on $3,044,670$ families surveyed in the FAO 2003 census, there was an increase from 11.4 to $14.4 \%$ of families without livestock between the pre-drought period in 1998 and 2003 .
} 
of successful and failed restocking schemes would help the MAAHF, MRRD, other relevant ministries and donors review proposals for restocking projects.

\section{Credit schemes}

Restocking schemes may involve the provision of credit. Currently farm-level prices for sheep are generally favourable and have increased considerably since early 2003 (see Figure 1). This favourable market situation is confirmed by a number of projects in Afghanistan that are currently providing loans to rural households, a substantial portion of which are for small ruminants. In the recently launched Afghanistan Rural Microcredit Programme (ARMP) of the Aga Khan Development Network (AKDN) in the northeast of the country, loans to purchase and re-establish sheep flocks comprise over $30 \%$ of the total portfolio (A. Sirolla, personal communication). In Bamyan Province in the Central Highland region loans for sheep comprise nearly $50 \%$ of the total portfolio of the same ARMPIAKDN project. Repayment rates in both regions rates are satisfactory. This indicates that under current market structures, a variety of financial services programmes could be developed to assist farmers to restock with small ruminants. Combined credit and restocking schemes are probably an essential component of efforts to enable farmers and landless labourers who lost all their animals during fighting and drought to become livestock owners again.

\section{Growing and finishing of lambs}

The results in Chapter 3 show that the finishing of lambs to heavier weighs can be a profitable enterprise, especially if they can be marketed when prices are high. A number of pre-conditions have to be met to encourage farmers to start growing and finishing lambs. Among them are:

1. Making credit available to buy feed and to avoid farmers having to sell lambs in the autumn for cash.

2. Making credit available to buy animals if they do not have their own.

3. Using breeds with sufficient genetic potential.

4. Feeding of balanced diets.

5. Providing appropriate health care and housing.

Farmers that own a few lambs need loans lasting at least six months with favourable repayment terms to purchase feeds, vaccines and other medicines. Farmers without livestock would also need to use the loan to purchase ewes and lambs. The types of loan schemes needed for purchasing lambs are very similar to those discussed in the section on restocking. 
Afghanistan has a considerable diversity of sheep breeds, but published information about their distribution and genetic characteristics is limited (Yalcin, 1979). The largebodied fat-rumped Turki breed which is concentrated in north-east Afghanistan is popular because well-fattened mature rams can sell for up to US $\$ 300$ (see Plate 2) However, unless the cost of the diet is very low, the profit from finishing these mature rams would be reduced since at higher live weights growth rate is lower because a high proportion of the gain is fat. That farmers in the north of Afghanistan are fattening a few Turki lambs to exploit the market opportunities indicates that reasonable profits can be made, even on the simple diets used. In the south of the country there is a wider diversity of sheep breeds and well-finished animals can reach a price of US $\$ 250$. There is an urgent need to investigate the extent to which genetic potential is influencing the growth of sheep under different nutritional regimes. Simple on-farm trials are needed to provide this information and to identify which breeds are best suited to different feeding regimes. It is therefore difficult at this juncture to make recommendations about which breeds are the most suitable for income generation from finishing.

Balancing the nutrients in diets for growing and finishing lambs depends heavily on the availability of feedstuffs already produced in the country (Table 16). The best pastures

Table 16. Areas ('000 ha) of crops that produce residues, grains or oil cakes suitable for used for feeding to livestock'. (Source: FAOSTAT)

\begin{tabular}{|c|c|c|}
\hline & 1961-70 & $1997-99$ \\
\hline \multicolumn{3}{|l|}{ Cereal crops ${ }^{2}$ : } \\
\hline Wheat & 2,226 & 2,112 \\
\hline Rice & 211 & 167 \\
\hline Maize & 491 & 187 \\
\hline Barley & 337 & 193 \\
\hline Millet & 28 & 27 \\
\hline \multicolumn{3}{|l|}{ Oil crops: } \\
\hline Cotton & 76 & 60 \\
\hline Flax (linseed) & 47 & 39 \\
\hline Sesame & 33 & 35 \\
\hline Sunflower & 8 & 12 \\
\hline Pulses ${ }^{3}$ : & 24 & 27 \\
\hline Sugar beet & 4 & - \\
\hline Sugar cane & 2 & 2 \\
\hline \multicolumn{3}{|c|}{$\begin{array}{l}{ }^{7} \text { Not shown here is the area of alfalfa and } \\
\text { Persian clover that many farmers grow. } \\
{ }^{2} \text { The grain of wheat and rice is used for } \\
\text { human consumption but the grain of maize } \\
\text { and barley is used as livestock feed. } \\
{ }^{3} \text { Mung beans, lentils, chickpeas. }\end{array}$} \\
\hline
\end{tabular}

are located in the hilly and mountainous areas of the Hindu Khush which extends from the north-east into the central region of the country ${ }^{28}$. They are grazed in summer by adult livestock and their offspring that are generally born in spring, and by replacement $\operatorname{stock}^{29}$. However, due to the severe winters, shortages of feed and poor access, these areas are less suitable for finishing lambs over winter except on a very limited basis.

\footnotetext{
${ }^{28}$ Since the fall of the Taleban in late 2001 the flocks of the Kuchi no longer have access to the best summer pastures in the mountainous central region of Afghanistan called the Hazarajat. This is a consequence of the historical resentment the Hazara people feel towards the Kuchi who are usually Pashtoons and it is claimed that they supported the Taleban after 1996.

${ }^{29}$ Afghanistan has $290,000 \mathrm{~km}^{2}$ of rangeland which is an area about $19 \%$ larger than the total area of the United Kingdom. Across the south and in the west of the country, which are the most arid areas, biomass production is well below the production in the central Highlands and the north and north-east of the country where precipitation is higher.
} 
The areas at lower altitude, where winters are less severe and crop residues are more available, are better suited for finishing lambs for sale in late winter and spring when prices are higher. However, without access to carefully designed credit schemes the decision to sell may depend on a family's needs for cash rather than on market prices.

Unless a source of cheap imported feed grains can be found, crop residues will remain a major component in the diet for growing and finishing animals. Because wheat is grown on the largest area, its straw will be the main roughage component in these diets (Table 16). The interviews with farmers revealed that cottonseed cake is usually a part of the diet for livestock in the north-east, whereas in the south, maize grain is often fed. Small amounts of various other ingredients are also mixed in the diet depending on the province and the crops grown. These include barley, rice and mung-bean straw, maize grain and stover, barley grain, cottonseeds, various oil cakes and hays of alfalfa and Persian clover. The areas sown to some of these crops are still below the areas sown in the 1960s and a shortfall in domestic supplies of feed grains and oil cakes is likely to continue into the future. This is because farmers give priority to growing food staples such as wheat and cash crops such as cotton, fruit crops and vegetables. However, if families find that marketing finished lambs is lucrative, they may be willing to grow a larger area of a feed crop such as barley and reduce the area of wheat. Thus, participatory feeding trials are needed to define optimal diets based on the best combinations of feedstuffs that are currently produced or available in the local markets.

\section{Growing and finishing of cattle}

The interviews in the villages showed that cattle such as oxen at the end of their working life are also finished for a few months in order to increase their market value. Similar diets can be offered to cattle as those offered to sheep. In cases where farmers own no cattle and wish to generate income from selling a few finished animals, the risks attached to loan schemes to purchase and feed cattle are higher than for sheep. This is because a loan for two or three years would be needed to enable a bull to reach a marketable weight and the death of a bull is a greater loss than the loss of one sheep out of four. Little is known of the genetic characteristics of the indigenous breeds and research is needed before it can be stated whether cross-breeding with imported breeds is likely to result in any improvement in performance and income. It is likely that there is considerable genetic diversity among the local breeds and a selection programme would make rapid progress. However, such programmes require a long-term commitment and they are expensive to operate. It is therefore preferable to use artificial insemination to spread improved milk and meat producing characteristics among the existing population of cattle. 


\section{Comparing income generation from selling livestock and growing poppies}

To explore whether the sale of livestock could provide an alternative to poppy production the example of finishing sheep was chosen. The question that needs to be asked is 'Could farmers be persuaded to grow a smaller area of opium poppies if they could sell finished livestock instead?' Two different approaches have been used to answer this question.

The first approach is to assume that the mean annual household expenditure of one person is US\$229 (Mansfield, 2004, page 55). A. Sirolla (personal communication) reported a similar figure of US $\$ 283$ for the north-eastern provinces. If the margin on the sale of one finished sheep was small at US $\$ 23$, then 10 would have to be sold annually to meet the

Table 17. Indicative gross income, production costs and gross margins from growing 0.3 ha poppies at two prices of the fresh resin'. (US $\$ / 0.3$ ha) (Source: $R$. Favre)

\begin{tabular}{lcc}
\hline & \multicolumn{2}{c}{$\begin{array}{c}\text { Price of fresh } \\
\text { resin (US\$/kg) }\end{array}$} \\
\cline { 2 - 3 } & $\mathbf{1 0 0}$ & $\mathbf{3 0 0}$ \\
\hline Gross & 1,530 & 4,600 \\
income & & \\
$\begin{array}{l}\text { Production } \\
\text { cost }\end{array}$ & 480 & 610 \\
$\begin{array}{l}\text { Gross } \\
\text { margin }\end{array}$ & 1,050 & 3,990 \\
$\begin{array}{l}\text { TAssumes a yield of } 46 \mathrm{~kg} \text { fresh resin/ha } \\
\text { and a typical family growing } 0.3 \mathrm{ha}\end{array}$ \\
poppies.
\end{tabular}
annual expenditure of one person. If the margin from the sale of a sheep was US $\$ 70$, only 3.3 finished sheep would have to be sold annually. In the study of Mansfield (2004) the mean family size was 14.7 persons in the villages sampled in Laghman and Nangarhar Provinces. Thus, to cover the monthly expenses of the whole family, 12 finished sheep would have to be sold if they made a margin of US $\$ 23$ each, or four if the margin was US $\$ 70$ for each sheep sold. Clearly, a family would not depend alone on selling finished sheep for its livelihood. Indeed, it would still have to own at least 100 sheep or buy, fatten and sell 50 head annually for them to make a substantial contribution to the family's livelihood.

The second approach is to compare the gross margins from growing poppies with the income generated from selling finished sheep. The information used to estimate the gross margins from growing 0.3 ha poppies is shown in Table 17. As the UNODC (2004) shows, the price of poppy resin can vary considerably across years. Although the margin from selling a finished sheep is between US $\$ 23$ and US $\$ 70$ it is also difficult to estimate the arable land requirement to produce one finished sheep because the type of diet varies so widely. In general though, fattening and finishing a few animals makes few demands on scarce arable land since they are fed largely on crop residues, oilseed cakes and some purchased feeds. Moreover, the manure from the animals can be used to enhance soil fertility or as fuel. Even though there are difficulties when comparing the margins from the two products, it is clear that the sale of sheep has a limited potential as an economic alternative to poppy growing. If the price of resin is 
US $\$ 100 / \mathrm{kg}$ between 15 and 45 sheep would be needed to generate the same margins as from 0.3 ha of poppies. If resin is US $\$ 300 / \mathrm{kg} 45$ to 135 sheep would be needed.

The above analysis assumes that income incentives are the determinants of farmers behaviour and that they behave in an economically rational way. There will be many other factors that determine the choice of farming activities, including risk. The risk associated with re-stocking with livestock was a recurrent theme in the interviews with farmers. The identification and promotion of alternatives sources of income is part of a much wider attempt to curb poppy growing and this study has shown that with a high demand for meat that livestock can play an important part in Afghanistan's agriculture and economy. What is now needed are policies and schemes to support and encourage the expansion of the national herd with sufficient attention to the detail of individual schemes to reduce the initial risk associated with re-stocking to encourage families to return to livestock husbandry, to expand herds/flocks and to develop systems that increase returns. 


\section{CHAPTER 8. CONCLUDING REMARKS}

The overall purpose of the RALF programme is to 'develop and promote innovative alternative livelihood options for rural Afghans currently economically dependent on opium poppy'. The specific goal of this short project was to 'identify market opportunities for livestock and livestock products and constraints to producers receiving higher returns from livestock products' as a viable alternative to poppy growing. The project showed that there are a number of market opportunities that could enable farmers to generate more income from selling animals. This is conditional on them already owning sufficient animals and producing enough feed or having access to credit with favourable conditions to purchase animals, feeds and medicines. Schemes to re-introduce carpet making linked with Afghan-based exporters that used a recognised quality label would add value to wool that is otherwise used in the household. Farmers would not perceive the benefits in terms of higher skin and hide prices if tanneries and production of leather goods were established in Afghanistan, assuming these were economically viable in a highly competitive global market, although there might be benefit to the economy as a whole.

Marketing constraints to producers receiving higher returns were identified, in particular the informal payments that traders and transporters have to pay at the numerous checkpoints. If central government took action to remove these unofficial payments the marketing costs would be reduced and the farm-level price could increase. The size and value of the red meat market is likely to grow over the coming years as herd inventories recover and demand of urban consumers increases. However, domestic supplies of red meat may not be sufficient to meet this growing demand and prices of domestically produced chicken meat are likely to remain higher than low-price imports. Therefore, imports of frozen chicken meat and live chicken from countries such as Pakistan are likely to continue since they satisfy the demand of the less wealthy urban families.

It is concluded that the future prospects to increase the incomes of rural families from selling finished animals are favourable but this will be due to the sale of more rather than higher priced animals. To generate the same income from selling animals as the income generated from a small area of poppies would require a family to sell more animals than most families are likely to own. Therefore, producing and marketing live animals for sale would only provide a partial alternative to growing poppies. To provide a real alternative (to poppy growing) higher incomes would need to be generated from selling more animals combined with higher returns from various combinations of field and vegetable crops, orchards crops, labouring and remittances. Merely selling a few finished animals each year would not in itself be sufficient incentive to persuade farmers to stop growing poppies for opium. Despite this, restoring livestock ownership is an important element of strategies to reduce rural poverty in Afghanistan, particularly in the case of landless 
families in which livestock ownership could be a significant part of their livelihood strategy. 


\section{BIBLIOGRAPHY}

Altai Consulting, 2005. Market sector assessments: SME developments. Report to UNDP. Altai Consulting, Kabul, March 2005. 257pp.

Barfield, T.J. 2004. Nomadic pastoralists in Afghanistan: Reconstruction of the pastoral economy. Bank Information Center, Washington DC. 19 pp.

Barrett, C.B., Bellemare, M.F. and Osterloh, S.M. 2004. Household-level livestock marketing behavior among Northern Kenyan and Southern Ethiopian Pastoralists. Working Paper 2005-11. Department of Applied Economics and Management, Cornell University.

CSO (Central Statistical Office), 1978. Afghan Agriculture in Figures. Statistical Yearbook 1360 (1983). Kabul.

CSO (Central Statistical Office), 2003. Afghan Statistical Yearbook 1382 (2003). Kabul.

Chemonics, 2004. Afghanistan poultry sub-sector assessment: Findings and recommendations. (Draft report). Rebuilding Agricultural Markets Program (RAMP), Chemonics, Kabul and Washington.

Delgardo, C., Rosegrant, M., Steinfeld, H., Ehui, S. and Courbois, C. 1999. Livestock to 2020: The next food revolution. IFPRI, FAO and ILRI. Food, Agriculture and the Environment Discussion Paper 28, IFPRI, Washington DC.

Demirüren, A.S. 1975. The present state of the world Karakul sheep industry and the future prospects. In: Proceedings of the Third International Symposium on Karakul Sheep Breeding. (Editors: S.A. Asamov and others.). Samarkand. pp 5-11.

De Weijer, F. 2002. Pastoralists vulnerability study. Afghan Food Security Unit/Vulnerability Assessment Mapping Unit, WFP, Kabul. 33 pp.

Dupree, L. 1973. Afghanistan. Princeton University Press.

FAO (Food and Agriculture Organisation of the United Nations), 2003. Afghanistan: National Livestock Census 2003. FAO, Rome.

FAOSTAT, 2005. FAO, Rome. (www.faostat.fao.org)

Ford, R.S. 1986. The Economy (Chapter 3). In: Afghanistan: A country study. (Editors R.F. Nyrop and D.M. Seekins). Foreign Affairs Studies, The American University. Washington DC. 
Fry, M. 1974. The Afghan economy: money, finance and the critical constraints to economic development. Leiden: Brill.

Hakimi, M.Y. 1976. The nature of livestock marketing and meat consumption per capita in Afghanistan. Kabul. USAID, Kabul. 35pp.

Government of Afghanistan, 2004. Securing Afghanistan's Future. A Government/International Agency Report Prepared for International Conference, March 31 April 12004

ICARDA (International Center for Agricultural Research in the Dry Areas), 2002. The Feeds, Livestock and Rangeland Sub-sectors in Afghanistan. Report of a Needs Assessment commissioned by the Future Harvest Consortium to Rebuild Agriculture in Afghanistan (FHCRAA) of the CGIAR. (Consultants: E.F. Thomson, T. Barker and J. Mueller), ICARDA, Syria. (www.icarda.cgiar.org/afghanistan/Need.htm)

Jost, C. 2004. Men, women, children and livestock: A livelihood analysis of the Afghan Registan Kuchi, focused on gender and animal health. Tufts University, North Grafton MA and Cordaid, Kandahar.

Kerven, C., Russel, A. and Laker, J. 2002. Potential for increasing producers' income from wool, fibre and pelts in Central Asia. Socio-economics and Policy Research Working Paper 45. International Livestock Research Institute (ILRI), Nairobi, Kenya. 40 pp.

Khan, U. and M. Iqbal. 1999. Role and the Size of Livestock Sector in Afghanistan. Draft report of a study commissioned by the World Bank, Islamabad, Pakistan.

Mahmood, K. and Rodriguez, A. 1993. Marketing and processing of small ruminants in highland Balochistan, Pakistan. Small Ruminant Research 10: 93-102.

Mansfield, D. 2004. Diversity and dilemma: Understanding rural livelihoods and addressing the causes of opium poppy cultivation in Nangarhar and Laghman, Eastern Afghanistan. A report for the Project for Alternative Livelihoods (PAL) in Eastern Afghanistan. PAL internal Document No. 2., GTZ, Kabul.

Mercy Corps Afghanistan, 2004. A Survey Conducted to Evaluate the Structure of the Wheat Trade Industry in Afghanistan. Report to the World Bank.

NRVA (National Risk and Vulnerability Assessment), 2003. Ministry of Rural Reconstruction and Development, Kabul.

(http://www.mrrd.gov.af/vau/NRVA 2003.htm) 
Rodríguez, A., Ali, I., Afzal, M., Shah, N.A. and Mustafa, M. 1994. Price expectations of sheep and goats by producers and intermediaries in Quetta market, Pakistan. Agricultural Economics. 12: 79-90.

Schroeder, T. C., Berkley, A.P. and Schroeder, K.C. 1995. Income growth and international meat consumption. Journal of International Food and Agribusiness Marketing 7: 15-30.

Thieme, O. 1996. Afghanistan: Promotion of Agricultural Rehabilitation and Development Programmes: Livestock Production. Project TCP/AFG/4552. FAO, Rome, Italy.

Thomson, E.F., Barker, T. and Mueller, J. 2003. Drought, livestock losses and the potential for feed production from arable land in Afghanistan: A case study in 183 villages with mixed crop/livestock production systems. Integrated Natural Resource Management Technical Report Series No. 2. International Center for Agricultural Research in the Dry Areas (ICARDA), Aleppo, Syria. (www.icarda.cgiar.org/afghanistan)

UNODC (United Nations Office on Drug Control), 2004. Afghanistan opium survey 2004. UNODC, Geneva and Counter Narcotics Directorate, Government of Afghanistan, Kabul.

World Bank, 1979. Livestock - The Development Challenge. A sub-Sector Survey: Afghanistan. World Bank, Islamabad, Report No. 2315-AF.

World Bank, 2005. Afghanistan: State building, sustaining growth and reducing poverty. World Bank, Washington.

Yalcin, B.C., 1979. The sheep breeds of Afghanistan, Iran and Turkey. FAO, Rome. 
Buffalos sold in Kabul originate from cities such as Peshawar, Faisalabad, Lahore and Karachi in Pakistan. Most are imported through the official Pakistani/Afghan border at Torkham but an unknown number are smuggled across the border in the mountainous region of south-east of Afghanistan. Cattle are also imported from Pakistan and some buffaloes and cattle may even originate in India. These imported animals pose a serious risk to animals in Afghanistan as they can carry highly infectious diseases such as footand-mouth into the country.

Although the numbers of animals arriving in the main livestock markets in Kabul are not recorded, the numbers of buffaloes imported have gradually increased over the years, partly in response to the reduced supply of local Afghan cattle following the drought. Traders reported that 12 years ago just a few live buffaloes were seen in Kabul's main livestock market. The second reason for the growing imports is the low price of cull buffalo cows in markets as far away as Karachi (Table A1). From there the journey to Kabul by truck takes $6-8$ days which puts considerable stress on the animals. It also results in high transport costs, customs charges at the border and other informal charges due to

Table A1. Estimate of the margin made by a trader buying a buffalo cow in Karachi and selling it to a butcher in Kabul.

\begin{tabular}{lr}
\hline & US\$ (Rps) \\
Sale price in Kabul & $571(32,000)$ \\
Purchase price & $357(20,000)$ \\
Transport charges & $89(5,000)$ \\
Customs, other charges & $107(6,000)$ \\
Trader's margin & $18^{1}(1,000)$ \\
\hline The range quoted was US\$18 to 36 per \\
head.
\end{tabular}
the many checkpoints along the way. Despite all of these expenses the trader's margin is between US $\$ 18$ and US $\$ 36$ per buffalo, or 3-6\% of the sale price. However, margins can decrease to zero if traders have to pay any additional informal charges or they are unable to sell the animals immediately and therefore incur additional costs to feed and house them.

No statistics about the numbers of buffaloes arriving in Tia-e-Maskin Market in Kabul are kept but an interview with one market official allowed an estimate to be made. He estimated that four or five trucks each loaded with 10 buffaloes arrive at the market each day. This is equivalent to between 12,000 and 15,000 head annually. They would have a sale value of between US $\$ 7$ and US $\$ 9$ Million. If one buffalo yields $175 \mathrm{~kg}$ meat, then between 2,000 and 3,000 tonnes of meat would be supplied to the Kabul market. If a similar number of buffalo are being sold at Kabul's second livestock market, then the values and volumes traded would increase proportionately. These volumes and values compare with the estimated 50,000 tonnes of frozen chicken imported into Afghanistan which has an estimated wholesale value of US\$72.6 million (Chemonics, 2004). Nearly half of this volume is delivered to Kabul. 
Buffalo meat is filling a gap in the supply of Afghan beef to the Kabul market. It is speculated that if the human population of Kabul is 3 million, annual per capita consumption of buffalo meat is 1 to $2 \mathrm{~kg}$ in Kabul. 


\section{ANNEX 2. QUESTIONNAIRE USED FOR THE LIVESTOCK TRADER SURVEY.}

Survey \#

\section{Trader Questionnaire- \\ Livestock Markets in Afghanistan}

The purpose of this survey is to gather information on the livestock trade in Afghanistan to help the government in developing policies that best serve the interests of livestock producers, traders, and consumers. The answers you give to the following questions will be kept confidential.

Enumerator

Date

Survey Location

Name of Trader

\section{General}

1. Are you a livestock producer (farmer) or trader? [Did you raise the animals that you are selling?]

Producer Trader Both

2. Do you own the animals that you are trading?

Yes

No

Both

3. How long have you been in business of selling livestock?

4. What percent of people trading in the market do you think are traders and what percent are producers/farmers?

$\%$ producer/farmer $\%$ trader

5. How many people do you think trade in this market on an average day?

\section{Sales and Trading}

6. What are the animals that you are selling in this market today?

\# Sheep

\# goats

\# of cows

\# of buffalo 
7. Do you have to pay a fee to sell your animals at this market? Yes No

8. How much is this fee? Cost per sheep

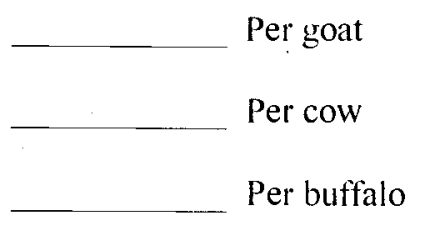

9. Do you own transport?

Yes

No

10. Do you rent transport?

Yes

No

11. Did the animals that you are selling today come here by truck or were they herded?
(circle one)
Trucked
Herded

12. What is the cost for the transport of animals? (please describe)

Trucking fee

From where

Distance traveled?

Other

13. Are the animals you are selling acquired locally or from outside the province?

$$
\text { Local outside }
$$

14. If you are selling animals from outside the province where are they from?

15. What is the price of the sheep

that you are selling?

(liveweight)

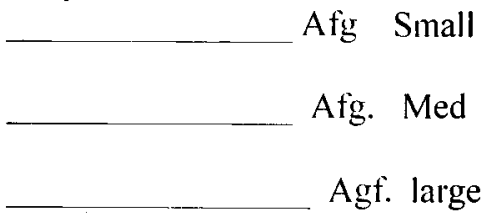

16. What is the price of the cows that you are selling? Afg. Small

Afg. Med.

Afg. Large 
17. What factors most influence the price of the animal?

Weight Quality Male/Female Castrated/Not Castrated Other

18. Generally, do you buy your animals from other traders or producers/farmers?

(circle) Trader $\quad$ Producer/farmer

\section{Volume of Trade}

19. If you are a trader, how many animals do you sell in one month?

20. Is the volume of animals traded throughout the year relatively stable? Yes

21. If it varies, what is the season when you have the highest volume of trade?

(circle one) Summer $\quad$ Fall Winter Spring

What is the period when you have the lowest volume of trade?

(circle one) Summer $\quad$ Fall $\quad$ Winter $\quad$ Spring

For the period of high volume of trade how many animals do you sell in I month? sheep and goats cows

For the period of low volume of trade how many animals do you sell in 1 month? sheep and goats cows

For the period of high volume of trade What is the price of the animals sheep cows

For the period of low volumes of trade What is the price of the animals sheep

\section{Industry Regulation}

22. Are there government regulations for the selling of animals here? Yes No 
23. Do you have to obtain licenses to trade your animals? Yes No

24. Are you required to make any unofficial payments? Yes No If yes, what is it?

25. Do you have any suggestions for how government policies or investments can improve the livestock market trade?

\section{Credit/Finance}

26. Have you applied for a loan from the bank? Yes No

27. Did you receive a loan from the bank? Yes No

28. Do you have access to friends or family who would provide you with credit?

$$
\text { Yes No }
$$

29. What is the maximum quantity of credit that you could obtain?

\section{General}

30. Do you own a mobile telephone? Yes No

31. Do you own your own home? Yes No

32. What is the highest level of school you attended? (circle one)

No School Elementary Secondary College/Post-secondary

33. What are the 2 most important problems you have for trading your animals?

1.

2. 
ANNEX 3. PRICES OF SKINS, LEATHER, AND FIBRES.

Prices of processed skins and leather

\begin{tabular}{lcccccc}
\hline $\begin{array}{l}\text { Type of } \\
\text { skin or } \\
\text { leather }\end{array}$ & Unit & \multicolumn{2}{c}{ Wholesale price } & \multicolumn{2}{c}{ Retail price } & Margin \\
\cline { 3 - 7 } & & (Afs) & US\$ & Afs & US\$ & $\mathbf{( \% )}$ \\
\hline Sheep & Skin & 230 & 4.8 & 250 & 5.2 & 9 \\
Goat & Skin & 220 & 4.6 & 250 & 5.2 & 14 \\
Lamb & Skin & 80 & 1.7 & 100 & 2.1 & 25 \\
Cattle & Seer & 1,800 & 37.5 & 2,000 & 41.7 & 11 \\
Buffalo & Seer & 1,250 & 26.0 & 1,400 & 29.2 & 12 \\
Camel & Seer & 1,250 & 26.0 & 1,400 & 29.2 & 12 \\
\hline
\end{tabular}

Wool prices paid by traders to merchants selling uncleaned (raw) wool from different origins

\begin{tabular}{lllcc}
\hline Colour & Market & Source & US\$/kg & Afs $/ \mathbf{k g}$ \\
\hline White & Kabul & Afghan & 1.0 & 48 \\
White & Kabul & Iran & 0.7 & 34 \\
White & Kabul & Iraq & 1.1 & 51 \\
White & Kabul & Iran & 1.6 & $70-80$ \\
White & Kabul & Turkmenistan & 1.0 & 50 \\
White & Kandahar & Afghan & 0.8 & 38 \\
Mixed & Kabul & Afghanistan & 0.6 & 29 \\
Mixed & Kabul & Iran & 0.4 & 19 \\
Mixed & Kabul & Iraq & 0.4 & 21 \\
Mixed & Kandahar & Afghanistan & 0.7 & 32 \\
Mixed & Kabul & Turkmenistan & 0.6 & 30 \\
Black & Kabul & Afghanistan & 0.5 & 24 \\
Black & Kabul & Iran & 0.6 & 27 \\
Black & Kabul & Iraq & 0.4 & 19 \\
Black & Kabul & Turkmenistan & 0.4 & 21 \\
\hline
\end{tabular}


Wool prices paid by traders to merchants selling cleaned wool from different origins

\begin{tabular}{lllcc}
\hline Colour & Market & Source & US\$/kg & Afs $/ \mathbf{k g}$ \\
\hline White & Kabul & Afghan & 3.3 & $150-170$ \\
White & Kabul & Afghan & 2.4 & 113 \\
White & Kabul & Iran & 1.8 & 88 \\
White & Kabul & Iraq & 2.4 & 113 \\
White & Kabul & Iraq & 3.1 & 150 \\
Mixed & Kabul & Afghan & 1.4 & 69 \\
Mixed & Kabul & Iran & 1.2 & 60 \\
Mixed & Kabul & Iraq & 1.2 & 58 \\
Black & Kabul & Afghan & 0.9 & 44 \\
Black & Kabul & Iran & 1.0 & 46 \\
Black & Kabul & Iraq & 0.9 & 45 \\
\hline
\end{tabular}

Prices of woollen yarn in Kabul (sources not determined)

\begin{tabular}{llcc}
\hline Colour & Market & US\$/kg & Afs $/ \mathbf{k g}$ \\
\hline White & Kabul & 5.0 & 240 \\
White, pale & Kabul & 3.8 & 180 \\
Dark white & Kabul & 3.3 & 160 \\
Black & Kabul & 2.9 & 140 \\
\hline
\end{tabular}

Prices of woollen yarn in Kabul

\begin{tabular}{lllcc}
\hline Colour & Market & Source & US\$/kg & Afs $/ \mathbf{k g}$ \\
\hline White & Kabul & Afghan & 4.3 & 206 \\
White & Kandahar & Afghan & 2.0 & 95 \\
White & Kabul & Iran & 4.3 & 205 \\
White & Kabul & Iraq & 3.7 & 180 \\
White & Kabul & Turkmenistan & 3.2 & 154 \\
Brown & Kabul & Afghan & 3.2 & 154 \\
Brown & Kandahar & Afghan & 1.2 & 57 \\
Black/grey & Kandahar & Afghan & 0.8 & 38 \\
\hline
\end{tabular}

Prices of uncleaned black goat hair and spun goat hair

\begin{tabular}{lllcc}
\hline $\begin{array}{c}\text { Type of goat } \\
\text { hair }\end{array}$ & Market & Source & US\$/kg & Afs/kg \\
\hline Uncleaned & Kandahar & Afghan & & \\
Spun & Kandahar & Afghan & 0.5 & 23 \\
\hline
\end{tabular}


Quantities of wool traded

\begin{tabular}{|c|c|c|c|c|c|}
\hline Market & & $\begin{array}{l}\text { Quantity raw } \\
\text { wool } \\
\text { purchased } \\
\text { annually (kg) }\end{array}$ & $\begin{array}{l}\text { Quantity cleaned } \\
\text { wool purchased } \\
\text { annually }(\mathrm{kg})\end{array}$ & $\begin{array}{c}\text { Origin of } \\
\text { most of raw } \\
\text { wool in } 2004\end{array}$ & $\begin{array}{c}\text { Origin of } \\
\text { most of } \\
\text { cleaned wool } \\
\text { in } 2004\end{array}$ \\
\hline Kabul & Trader 1 & 10,000 (in 2004) & 30,000 (in 2004) & $\begin{array}{l}\text { Iraq }(10,000 \\
\text { kg), Saudi } \\
\text { Arabia }\end{array}$ & $\begin{array}{c}\text { Saudi Arabia } \\
(30,000 \mathrm{~kg})\end{array}$ \\
\hline Kabul & Trader 2 & 25,000 (in 2004) & 40,000 (in 2004) & $\begin{array}{c}\text { Iraq }(18,000 \\
\mathrm{kg})\end{array}$ & $\begin{array}{l}\text { Iraq, Kuwait } \\
(35,000 \mathrm{~kg})\end{array}$ \\
\hline Kandahar & Trader 3 & 6,750 & Zero & & \\
\hline Kandahar & Trader 4 & 22,500 & 3,600 & & \\
\hline Kandahar & Trader 5 & 3,600 & Zero & & \\
\hline
\end{tabular}




\section{ANNEX 4. NOTES ON THE WOOLLEN MILLS IN KABUL AND KANDAHAR.}

\section{The Woollen Mill at Pule Charkhi, Kabul}

A West German company constructed the woollen mill at Pule Charkhi in 1965 which operated privately until 1975 when the government took over ownership. Up to 400 workers were employed by the mill during the early years but in early 2005 it only employed 107. The mill continued operating until 1992 when heavy fighting between mujahaddin factions damaged the buildings and machines and cut the electricity supply. The employees fled. The mill opened again in late 2001 following the defeat of the Taleban. The government still owns the buildings and plant but the operating expenses and the salaries of the employees are paid out of the income from the sales of woollen products. Since it started functioning again the mill it has been operating at a reduced capacity since the machines are antiquated, many dating from the 1960s. The mill only operates at night when there is a fairly reliable electricity supply.

As in the past, the mill continues to purchases raw wool from local suppliers and processes it into woollen yarn which is suitable for military uniforms, blankets and carpets. In the past, $75 \%$ of the products were destined for the Ministries of Defence, Interior and Security, and the remainder was sold to private buyers. Today the Ministry of Defence is one of the main buyers of the outputs of the mill. In 2004 its production target was $10,000 \mathrm{~m}$ of machine-made carpets of either 70 or $140 \mathrm{~cm}$ width and about 27,000 woollen blankets, each with an area of $2.2 \mathrm{~m}^{2}$. However, actual production was only $3,000 \mathrm{~m}$ of carpets and 7,000 blankets.

Wool sourced from Afghanistan is purchased in April, May and June when shearing of most sheep takes place. Previously most of the wool was purchased from the Kuchi because families might own several hundred sheep between them. The 2004 wool price of uncleaned wool was US $\$ 0.70-0.80$ but the colour of this wool was not recorded. Prices of products from the mill quoted in early 2005 were as follows.

- Carpets up to $30 \mathrm{~m}$ length, $70 \mathrm{~cm}$ wide, US $\$ 7.30 / \mathrm{m}$

- Carpets up to $30 \mathrm{~m}$ length, $140 \mathrm{~cm}$ wide, US $\$ 14.60 / \mathrm{m}$

- White and plain blankets $\left(2.2 \mathrm{~m}^{2}\right)$, US $\$ 7.70$ each

- Dyed and patterned blankets $\left(2.2 \mathrm{~m}^{2}\right)$, US $\$ 9.00$ each

- Plain white woollen yarn, US\$2.10/kg

- Dyed woollen yarn, US\$2.70/kg

The price of the machine-made plain white woollen yarn is a quarter to a third less than the price of hand-processed and spun white woollen yarn quoted by traders in Kabul. Apart from this difference, the quality of the two products may differ in other ways. 


\section{Old Woollen Mill, Hazratjehbaba area, Kandahar}

The old woollen mill in Kandahar City was constructed by a German company before the Second World War. It continued to operate until 1990 when fighting between the forces of Dr Najibullah and the mujaheddin damaged the buildings and machines. When the mill was operating, the 300 members of a local association of wool merchants purchased raw wool from the Kuchi in the south and south-east of the country and sold it to the mill. There it was processed into yarn which was used for making the cloth used in winter uniforms for the army, blankets, machine and hand-made carpets and patoothe shawl worn by Afghan men. Annual purchases of wool, all of it from Afghan sheep, peaked at 2,250 tonnes. This is equivalent to the clip from somewhat more than 1 million sheep out of a possible population of 20 million in the 1970s. These purchases compare with the peak national production of about 33,000 tonnes in the mid-1990s.

\section{The Nasaji Woollen Mill, Kandahar}

A West German company constructed the government-owned and operated Nasaji Woollen Mill in 1974 and it is fully operational. It is said to purchase 1,200 tonnes uncleaned wool annually from Afghanistan sheep owners and from Pakistan. However, the primary origin of the imported wool is not known. At the time of the interview the mill was paying Afghan suppliers US $\$ 0.40-0.79 / \mathrm{kg}$ uncleaned wool and US $\$ 2.70 / \mathrm{kg}$ for cleaned and imported fine wool, apparently from Merino sheep.

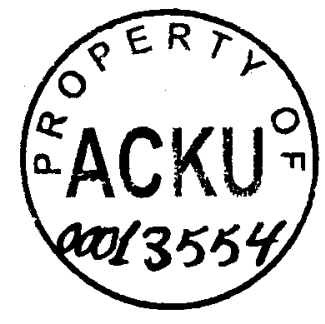

